\title{
Impact of Variation Orders on Construction Project Cost: A case study of Land Pooling Project at Kathmandu of Ichangu Narayan, Nepal
}

\author{
Aananda Raj Pokharel ${ }^{*}$, Buddhi Raj Joshi ${ }^{2}$ \\ ${ }^{1}$ Chairman, SAS Services Private Limited, Srijanachowk, Pokhara, Kaski, Nepal \\ ${ }^{2}$ Lecturer, School of Engineering, Faculty of Science and Technology, Pokhara University, Pokhara-30, Kaski, Nepal
}

DOI: $10.36348 /$ sjet.2020.v05i05.003

| Received: 07.05.2020 | Accepted: 14.05.2020 | Published: 19.05.2020

*Corresponding author: Aananda Raj Pokharel

\section{Abstract}

Government of Nepal has been planning to develop modern cities through land pooling programs as per the Town Development Act 2045. The study is conducted in Ichangu Narayan (Raniban) Land Pooling Project phase II and the status of variation orders, their origin, causes and impacts in project cost and completion time is analyzed to develop preventing measures which can be beneficial in upcoming similar projects. The objective of the research was to identify the types of variations and the origin and rank, to assess the impact of variation orders regarding cost and duration and to explore the preventive measures to minimize the variation orders. Primary data were collected from the questionnaire survey, key informant interview and field study. The secondary data were collected by means of desk study, relevant literature and text books review, maps and drawings and internet sources. From the study, main cause of variation orders impacting project completion time is known to be conflict between the contract documents and is originated from Consultant. Similarly, main cause of variation orders impacting project cost is additional work. 26.50\% (Rs $45,700,255.02)$ cost above the contract cost has been incurred directly at the completion of the project. $12.40 \%$ (Rs $21,380,129.70$ ) of contract cost has been paid for price escalation only. Similarly, $16.96 \%$ cost for the successive contract of the project has been increased by the extension of the contract duration. The appropriate recommendation has been given to the concerning parties involved in the construction work.

Keywords: Variation, Construction, Land Polling, Time, Cost.

Copyright @ 2020: This is an open-access article distributed under the terms of the Creative Commons Attribution license which permits unrestricted use, distribution, and reproduction in any medium for non-commercial use (NonCommercial, or CC-BY-NC) provided the original author and source are credited.

\section{INTRODUCTION}

A construction contract is defined as a business agreement that is subjected to variability. Variation orders consist of the additions, omissions, alterations and substitution in terms of quality, quantity and schedule of works.

Nepalese construction industry plays a vital and major role in the development of this country. One of the major problems faced by construction project is the issue of variation orders occurring during the construction phase which results in delaying projects, overruns the cost and causes other negative effects. Hence it is very important to control variation orders.

\section{BACKGROUND}

Success in managing variation orders results in uninterrupted construction operations and agreed project costs as well as duration [1]. Studies have revealed the significant reduction in both cost increase and time delay as a result of a complete design before commencement of works on site resulting in the prevention of variation orders [2]. Arguably, the more the occurrence of variation orders, the greater the likelihood that unnecessary costs could accrue impacting on the overall project cost [3]. Whenever a variation order is issued, unnecessary indirect costs are likely to be incurred. Koskela [4] indicated that every time a task is divided into two subtasks executed by different specialists, non-value-adding activities increase. By uncovering non-value-adding activities arising from variation orders it is possible to take preventive measures to reduce them. A clear understanding of variation orders and subsequent waste is possible if they are categorized by their origin and identification of possible waste zones. He suggested a framework of formation of waste and value loss that takes into account the following:

- Waste and value loss;

- Factors causing loss; and

- Root causes. 
Variation orders do not only affect project performance in terms of time and cost, they also adversely affect the quality, health and safety and professional relations [5]. However, factors influencing the occurrence of variation orders and their adverse impact on project performance vary from one project to another. Factors include the nature of works, the complexity of the project and the procurement method [3].

Ichangu Narayan (Raniban) Land Pooling Project (Phase II) is developed by Kathmandu Valley Development Authority (KVDA) in 2007 at ward numbers 7, 8 (Ka) and 8 (Kha) of Ichangu Narayan VDC (now Nagarjuna Municipality). The project has completed a contract with name "Construction of Bulk Water Supply System and Road Works" under "Contract No. 01/INLPP/BWSSRW 2071/72". The contract agreement between KVDA (INLPP) and Ashish/ Biruwa/ CM JV was made on 2014 December 16 with intended completion date of 2016 June 26 and contract amount of NRs 17, 23, 43,494.78 without VAT. The supervision of construction works was done internally by the project.

\section{Statement of Problem}

In almost cases, there is a variation order that occurs during the progress of the on-going of construction projects. This leads somehow increase the cost and duration of the project and affects its development. Increase in the additional value of the cost and duration is waste and this causes problems towards the contractors, consultant, clients and the users.

\section{Research Questions}

The key research questions addressed by the research are:

1. What are the types of variation orders and the causes behind them along with the origins Land Pooling Project

2. What is the impact of variation orders in the project under study regarding cost and duration of completion of the project?

3. What preventive measures can be taken in similar construction projects to reduce variation orders?

\section{Research Objectives}

The overall objective of this study is to analyze the impact of variation orders on project cost and duration.

The specific objectives are:

- To identify the types of variations and the origin and rank of causes of variation orders in IchanguNarayan

- To assess the impact of variation orders regarding cost and duration of completion of Ichangu Narayan Raniban Land Pooling

\section{Project}

- To explore the preventive measures to minimize the variation orders.

\section{Significances of the Study}

Nepal is planning to implement various land pooling projects through Town Development Act 2045 to establish well planned cities. The findings and recommendations of this research will help the planners, designers, employers, contractors and other related stake holders in similar other land pooling projects for their successful implementation by developing preventing measures to control or eliminate probable causes of variation orders.

This study is supposed to provide a clear view regarding the success of land pooling projects in prospective of cost and duration of completion.

The research mainly focuses in exploring a preventive approach to eliminate or reduce the complexity created by variation orders during construction in successful completion of project remaining within the premises of the time frame and the available budget. The research is expected to provide the developers, designers, consultants and the contractors the knowledge and idea about the problems that can arise during construction phase due to variation orders issued by any of the related parties. This helps the related stakeholders to plan a proactive approach to find a solution regarding the delay and cost overrun due to non-value adding activities like variation orders.

\section{LITERATURE REVIEW \\ Variation Orders in Construction Projects}

Contractual clauses relating to changes allow parties involved in the contract to freely initiate variation orders within the ambit of the scope of the works without alteration of the original contract. Variation orders involve additions, omissions, alterations and substitutions in terms of quality, quantity and schedule of works. Under contractual provisions, the client has the right to vary the extent and the nature of the performance to be rendered by the contractor [6].

Furthermore, the contractor could not refuse to carry out the varied obligation with the only remedy being an adjustment of price to be paid for the performance, and in appropriate circumstances, an extension of time in which to execute such performance [7].

Unfortunately, because construction projects involve complex operations which cannot be accurately determined in advance, variation orders occur. Arguably, variation orders cannot be avoided completely [8].

The disadvantage of the variation clause is that architects tend not to crystallize their intentions on 
Aananda Raj Pokharel \& Buddhi Raj Joshi., Saudi J Eng Technol, May, 2020; 5(5): 203-230

paper before the contract is signed because they know the variation clause will permit them to finalize their intentions during the term of the contract [6].

The nature of variation orders can be determined by referring to both the reasons for their occurrence and subsequent effects. Arain \& Pheng [5] distinguished two types of variation orders, namely: beneficial and detrimental variation orders.

A beneficial variation order is one issued to improve the quality standard, reduce cost, schedule, or degree of difficulty in a project [5]. According to Zimmerman \& Hart [9] all designs have unnecessary cost regardless of how excellent the design team may be. A beneficial variation order, therefore, seeks to optimize the client's benefits against the resource input by eliminating unnecessary costs. However, it should be noted that regardless of how beneficial a variation order might be non-value-adding costs are likely to accrue as a result.

\section{Contractual Provisions Related to Variation Orders}

Provisions for variation according to PPA [10] of Nepal states that unless otherwise provided for in the procurement contract, if the circumstances that could not be foreseen at the time of signing of procurement contract arise in the course of implementation of the procurement contract, the competent authority may, by stating clear reasons thereof, issue as prescribed, a variation order for a variation of up to fifteen percent and for a variation order above it, a variation order may be issued as per the decision made by the Government of Nepal Council of Ministers by complying with the procedure as prescribed in the case of the Public Entity under sub-clause (1) of clause (b) of Section 2 and in the case of other Public Entity as decided by the supreme executive body of such entity.

Finsen [7] identified five categories of contract instructions, namely, Instructions to vary the works, Instructions to resolve discrepancies, Instructions to reiterate or enforce contractual provisions, Instructions to deal with monetary allowance, Instructions to protect the client's interest. The instruction to vary the design, quality and quantity of the works and to resolve discrepancies in contract documents are variation orders.

Table 2.1: Classification of Contract Instructions

\begin{tabular}{|c|l|l|}
\hline No & Instruction category & Qualification \\
\hline 1 & $\begin{array}{l}\text { To vary the design, quality or quantity } \\
\text { of the works }\end{array}$ & Variation order \\
\hline 2 & To resolve discrepancies & Variation order \\
\hline 3 & $\begin{array}{l}\text { To reiterate or enforce contractual } \\
\text { provisions }\end{array}$ & $\begin{array}{l}\text { In some cases it may be a variation order if incidental to instruction } \\
1 \text { and 2 }\end{array}$ \\
\hline 4 & To deal with monetary allowance & $\begin{array}{l}\text { It may be a variation order if monetary adjustments are the result of } \\
\text { instruction number 1 and 2 }\end{array}$ \\
\hline 5 & To protect the client's interest & Not a variation order \\
\hline
\end{tabular}

\section{Origin of Variation Orders}

A study that focused on the point of view of developers of potential causes of variation orders suggested four main origin agents of variation orders [5]. These included "client", "consultant", "contractors" and "others". There is an interrelation between the origin agent and causes of variation orders.

The client as the project initiator plays a major role in the construction project from the inception to the completion phases. Clients anticipate the needs and objectives of projects, establish the scope of works and the required quality standards. During the construction stage, clients initiate variation orders due to various reasons.

Acharya et al., [11] suggested that consultants should aim at obtaining an understanding of the overall scope and goals of the project, be sure they understand deliverables and provide specific suggestions when required. All has to be done relatively quickly without having any negative effect on productivity.
Unfortunately, the feeling of superiority of the consultant over the contractor may hinder the consultant from giving attention to requests by the contractor.

It is the role of the consultant to advise the client on technical, legal and financial matters. The designer may, sometimes, be unaware of affordable alternative materials for finishes. Where deemed necessary, it is common for the consultant to issue a variation order for improvement purposes.

The involvement of the consultants in the design phase would assist in clarifying the project objectives and in identifying the non-compliance with their requirements at early stage which may help in eliminating the occurrence of variation orders arising from errors and design discrepancies during the construction stage where the impact of variation orders can be severe.

The continuous coordination and direct communication would not only eliminate design 
discrepancies and errors as well omissions in the design, but also professionals would be provided opportunities to review the contract document thoroughly which would help in eliminating the variation orders arising because of conflicts in contract documents.

\section{Causes of Variation Order}

According to Uyun [12], the drawings and specifications do not always show the real site conditions nor do preliminary investigations. Despite this situation, it is common that works commence on site while some trades and building elements still need to be completely designed or detailed. Consequently, contracts contain provisional quantities and sums that will be subject to future adjustment. Gidado [13] suggested four possible causes of project uncertainty, namely:

- Lack of complete specification for the activities to be executed;

- Unfamiliarity with the inputs and environment by management;

- Lack of uniformity, such as when material to be worked with varies with place and time or teams working together vary with place and time or the role of the teams keeps varying with place and time.

- Unpredictability of the environment, such as the effect of weather and refurbishment of very old buildings having no record drawings.

The complexity involves an item having two or more components or two or more variables. Two types of project complexity are distinguished, namely organizational or management complexity and technological or technical complexity $[14,15]$. The degree of project complexity is classified as low, medium and high complexity. The greater the project complexity, the greater the likelihood of variation order occurrence.

The participants in a construction project constitute a multi-organizational body generally including a client, designers, specialist consultants, project managers and constructors. The path followed to deliver the project differs from one project to another. Typically, this is a procurement method that stipulates the form of contractual arrangement between participants or parties to the contract. One type of procurement method may result in more variation orders than another.

\section{Waste Associated with Variation Orders}

Very often, waste has been referred to as physical losses of material occurring during the construction process. According to Formoso et al., [16], waste is defined as any inefficiency that results in the use of equipment, materials, labor, or capital in larger quantities than those considered as necessary in the production of the building. Ruben [3], stated that the quantity exceeding the allowable is non-recoverable because it constitutes a loss that was not budgeted for. Unfortunately the existing estimating and contract valuation techniques do not provide a clear breakdown of losses of materials resulting from variation orders. For example, cement that hardens in the stores following an instruction to suspend works is not allocated to the variation order account.

\section{Impact of Variation Orders on Project Performance}

It is rare that projects perform precisely in line with their original schedule due to reasons such as, for example, business condition changes, delivery slips, and corrections to design [17]. Ibbs [18] concluded that variation orders affect project performance as they adversely affect productivity and project costs.

\section{Cost Overruns}

Construction projects involve recognized phases of which two are particularly important, namely, pre-construction and construction phases. Construction phase typically consumes more resources than the preconstruction phase; attention to cost planning is focused on the construction phase. Clients prefer final construction costs to equate to the originally forecast tender figure. Unfortunately, many construction projects incur cost overruns. Omissions in most cases reduce costs while additions increase costs [19]. Various studies have revealed that variation orders contribute to these cost overruns. Arguably, the more the number of variation orders, the more they are likely to affect the overall construction delivery cost. In fact, variation orders have both a direct and indirect effect on cost. Direct costs constitute the additional costs incurred to perform the activities of the current variation orders. Bower [20] identified the following direct costs associated with variation orders:

While the direct costs associated with a variation order can be easily calculated, that indirect costs are more difficult to quantify. Indirect costs are costs incurred as a result of variation orders, whether they are apparently linked to them or not.

\section{Time Overruns}

Clients require their construction projects to be completed within minimum time limits. It is anticipated that projects finished within the shortest possible time achieve some monetary savings. Contractors are heavily penalized when they exceed the original project delivery date. The penalty imposed is meant to compensate damages suffered by the client owing to the prolonged delivery period. Several authors agree that variation orders present as one of the reasons for project time overruns [21]. It was found that variation orders issued during various phases of construction projects negatively affected both the completion time and costs of projects where the former category relieves the contractor of liability for liquidated damages and the latter is due to the contractor's culpable delay. 
Aananda Raj Pokharel \& Buddhi Raj Joshi., Saudi J Eng Technol, May, 2020; 5(5): 203-230

Quality Degradation

Contracts with a significant degree of risk for unknown variables such for example, lump sum, contractors may cut corners on quality and quantity to maximize profits. If variation orders are frequent, they may potentially affect the quality of works. Quality may be compromised as contractors try to compensate for losses they are not optimistic about recovering.

\section{Land Pooling Projects}

Land Pooling also known as Land Readjustment was first conceived in USA by George Washington in $1791 \mathrm{AD}$. The legislative origins of land readjustment were established in 1902 by Franz Adickes, mayor of Frankfurt-am-Main, Germany with the goal of improving the efficiency of farmland.

Nepal is a mountainous country covering 147,181 sq. Km. with 26.5 million people [22]. The annual population growth of Nepal was $1.35 \%$. Concentration of population and housing is very high in urban areas. Most of the urban areas of Nepal are unplanned where housing and infrastructures situation are worst.

The government is planning to develop Land Pooling Projects to develop modern cities through land pooling (readjustment) programs as per the Town Development Act 2045. Urban Development Act 2045, Para 12 (2) defines the land pooling and the procedures. The land pooling Manual 2061, compiled by SB Sangachhe and G.P Gorkhali, and published by Dept. of Town Development and Building Construction, Min. of Physical Planning and Construction, Govt. of Nepal, is guiding the land pooling/readjustment programs for urban development in Nepal. The users committee and project management committee will provide guidance for running land pooling the project.
The problems encountered of the implementation of land pooling projects are social feasibility or convincing land owners for land pooling, weakness of cadastral map and records, management of small parcels, location of returned parcel and financial problems. As the land pooling process involves wide extent and varieties of construction works in a large volume, the construction phase of Land Pooling Project is time consuming process. Variation of works due to change in requirement is common in Land Pooling Projects. Hence, a comprehensive study of factors causing variation can support on the development of preventive measures to control waste.

\section{METHODOLOGY \\ Research Design}

Research design is one of the major components of the whole research and it guides when, how and where the data will be collected. A brief research methodology has been presented below:

\section{Research Approach}

The research is based on both qualitative and quantitative approach. The research is analytical research. Direct analysis of the bills of quantity, bills approved by the Client for payment, letters, drawings, specifications, General condition of contract (GCC), special condition of contract (SCC) and similar documents are analyzed. Claim of the Contractor, time escalation reports are also analyzed.

Similarly, questionnaire survey is carried out with structured and semi- structured questions regarding the research objectives. Users having land plot or building inside the project area are included in survey. Key informants are interviewed with semi structured questions to verify the results of the questionnaire survey.

\section{Study Area}

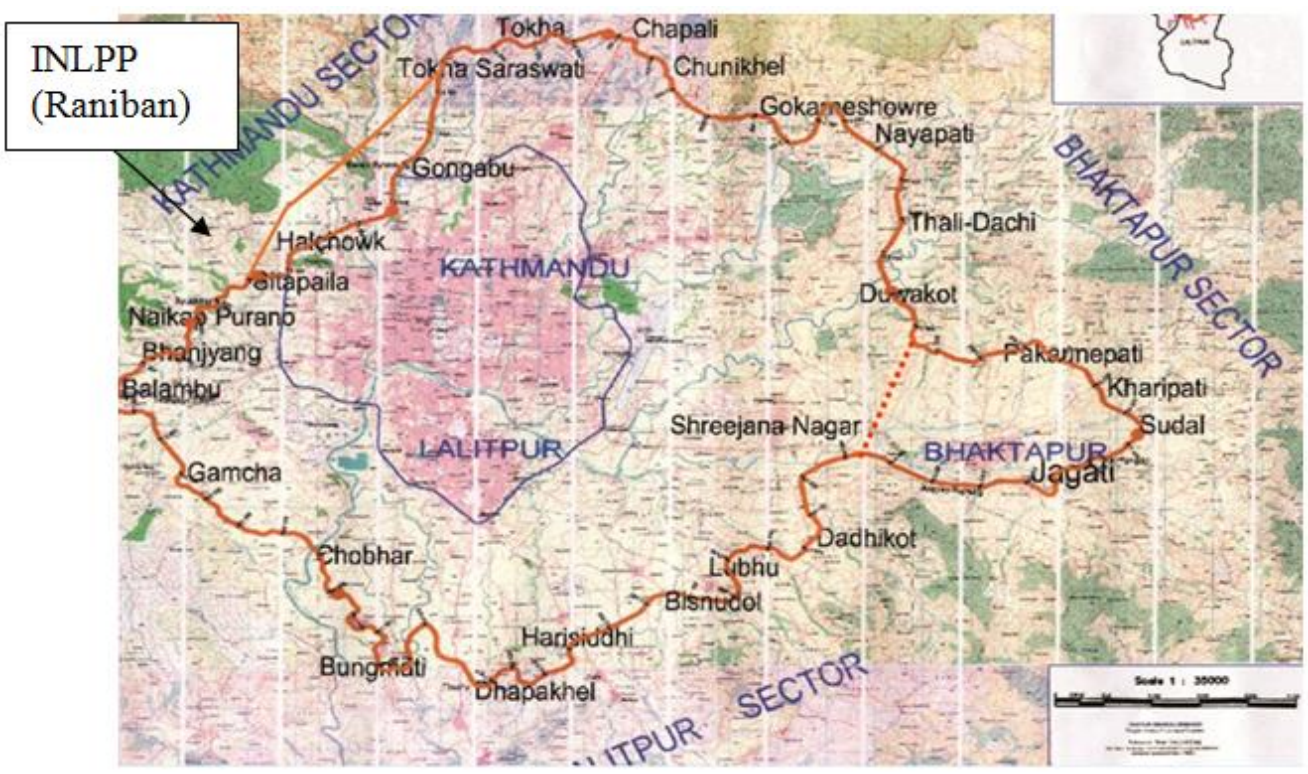

Figure 3.1: Location Map of INLPP (II) 
Ichangu Narayan (Raniban) Land Pooling Project (Phase II) is developed by Kathmandu Valley Development Authority in 2007 at ward numbers 7, 8 (Ka) and 8 (Kha) of Ichangu Narayan VDC (now Nagarjuna Municipality). This research is focused on the study of origin, causes and impacts of variation orders in construction of Ichangu Narayan (Raniban) Land Pooling Project (Phase II). The project includes 608 ropanis of land obtained from the land owners. The project expects to develop 1200 to 1500 plots of land and $3 \%$ of open space. However, till date, 1050 plots of land owned by 647 owners and 2.93\% (5 numbers) of open space have been developed. The project has already distributed ownership certificate (Lalpurja) to 989 plots and is continuously progressing in development of project.

The project has completed a contract with name "Construction of Bulk Water Supply System and Road Works" under "Contract No. 01/INLPP/BWSSRW 2071/72" which includes construction of asphalt concrete road and rigid pavement roads, construction of 150 cum underground water tank and 100 cum overhead water tank, water supply networking system, sewage line networking system, deep tube well works and construction of guard houses. The contract agreement between KVDA (INLPP) and Ashish/ Biruwa/ CM JV was made on 2014 December 16 with intended completion date of 2016 June 26 and contract amount of NPR $17,23,43,494.78$ without VAT. The supervision of construction works was done internally by the project.

\section{Study Population and Sample Selection}

The population under this study included all the land owners and building owners inside the project area. According to the Client, Lalpurja of 989 plots to 647 owners had been issued till November 2018 according to the project record. Those 647 owners were taken as the study population and sampling was done from the population to carry out questionnaire survey.

Convenient sampling method was used for sampling the study population (for questionnaire survey). For this, a probable respondent was visited as per the convinience. Question was asked if the family member of the respondent has already been selected for questionnaire to ensure that the respondent is not repeated. The probable respondent was requested to select a folded card from the pool of two cards indicating "YES" or "NO" in each folded card. The respondent who chose card indicating "YES" was selected for questionnaire. The respondent who chose card indicating "NO" was not selected for questionnaire. Again another respondent was visited in random and the process was repeated till the questionnaire survey was carried out to the required numbers of samples.

\section{Sample Sizes}

Cochran equation as given below was used to calculate the sample size of landowners. 90\% confidence level and confidence interval of 10 was used to calculate the sample size.

$n_{0}=\frac{Z^{2} p q}{e^{2}}$

For a finite sample this formula is modified as

$$
n=\frac{n_{0}}{1+\frac{\left(n_{0}-1\right)}{N}}
$$

Here,

$\mathrm{n}_{0}=$ size of infinite population,

$\mathrm{Z}=$ Area of normal curve and its value is 1.64 for $90 \%$ confidence level.

$\mathrm{e}=$ Desired level of precision (Confidence interval)

$\mathrm{p}=$ Estimated proportion of an attribute that is present in the population, and $\mathrm{q}$ is 1-p. N= Population Size (Land owners in this case)

Since the variability in the proportion is not known, therefore, maximum variability of 0.5 (i.e. $\mathrm{p}=\mathrm{q}=0.5$ ) is assumed. Using the above equations, sample size of landowners was calculated. The minimum required sample size is 61 numbers. However, 102 numbers of respondents were selected as sample.

Table 3. 1: Sample Size

\begin{tabular}{|l|l|l|l|}
\hline S/N & Population Size & Required Sample Size & Sample Size Taken Under Research \\
\hline 1 & 647 & 61 & 102 \\
\hline
\end{tabular}

\section{Data Collection}

\section{Data Collection Tools}

The following are the data collection tools used during this research:

- Field observation and Site Visit

- Review of Documents regarding Project and Contract

- Questionnaire Survey

- Key Informant Interview

\section{Method of Data Collection}

Primary Data Collection

1. Reconnaissance Survey: Ichangu Narayan (Raniban) Land Pooling Project (Phase II) site was visited and the progress of work was confirmed with reference to the final running bills claimed by the Contractor for verification. 
2. Questionnaire Survey: Questionnaire was used for the primary data collection. The questionnaire items were based on the general information of the respondents, causes of variation orders regarding time overrun, causes of variation order regarding cost overrun and effect of time overrun on cost overrun. The questionnaire was personally administrated by the researcher and that provided the researcher chance to interact with the respondents. Enough time was given to the respondents to answer the questionnaire (Questionnaire in Annex A). A five point scale was used to indicate the relative importance of each cause of variation order regarding time overrun and cost overrun where " 1 " represented extremely minor, "2" represented minor, "3" represented moderate, "4" represented major and " 5 " represented extremely major.

3. Key Informant Interview: The representatives of client, consultant, contractor and members of user's committee were included in key informant interview. As the questionnaire survey is carried out with the land owners and house owners only, key informants were asked with semi structured questions to confirm the compliance of the results of questionnaire survey.

\section{Secondary Data Collection}

Review of Project Related Documents: Documents related to the project was collected from the related offices for study as follows:

Contract Documents: The contracted Bill of Quantities, Design Drawings, General Condition of Contracts, Special Condition of Contract, Specifications, were studied for the research propose. The data was collected from the Contractor and the Client.

Interim Payment Certificates: All the Interim Payment Certificates approved from the Client for payment and pending bills was collected from the Contractor and the Client for the study of discrepancies from BoQ (Bill of Quantities).

Letters and Documents: Letters issued from the Client and the Contractor and also the design Consultant and the User's Committee, Letter of Extension of Time, Variation Orders, Site Instructions, Drawing Changes, Conformation of Verbal Instructions for either parties, Claim of the Contractor, and similar related documents were studied.

The secondary data for this research work was collected through different sources such as research papers, publications, guidelines, acts and policies, works done in similar field, journals and online information.

\section{Data Analysis and Presentation}

This study used both qualitative and quantitative data. The collected data were presented on the basis of quality and the nature of data.

The quantitative data was analyzed and presented in table, graphs and charts while the qualitative data was analyzed and presented to develop the logical sequence.

Variation orders issued in INLPP (II) were obtained from the Client. Response of questionnaire survey as designed carefully in light of getting response relating the causes of variation orders regarding project cost and time was tabulated and relative importance index (RII) of each causes was analyzed to determine their respective rank.

The relative importance index (RII) for each variable was computed by using the following formula:

$\mathrm{RII}=\frac{\Sigma W}{A * N}$ equation (1)

Where,

RII= Relative Importance Index

$\mathrm{W}=$ scale for weight in the scale (ranges from 1 to 5 )

$\mathrm{A}=$ the highest weight of the scale (equal to 5)

$\mathrm{N}=$ total number of respondents concerning each factor

Likert- type scale was used in analyzing qualitative data obtained from the questionnaires, which is suitable for ranking the statements of respondents' views by using the relative importance scale (RII). Relative importance index (RII) for each cause as responded by the respondents was calculated and overall ranking of the causes of variation orders was determined. Causes of variation orders were tabulated with respective to their origin; client, consultant, contractor and others and ranking of causes with respective to their origin was also developed. This helped to provide a clear picture regarding the causes of variation order; both in overall, and with respect to the origin of variation orders.

A key informant interview with the major stakeholders; client, consultant, contractor and user's committee was carried out after the analysis of questionnaire survey in order to confirm the compliance of results of questionnaire survey. The project manager, chief engineer and chief accountant from the client; designer of road networking works, designer of water supply system and designer of deep tube well works were selected from consultant; the director, project engineer and accountant from the contractor and the president, treasurer and secretary from the user's committee were selected and they were asked with semi structured questions relating to the results of questionnaire survey. 
Opinions of the representatives regarding the results were obtained from the semi structured questions where they were given a chance to elaborate their views on the results. Logical sequence was developed from the key informant interview.

Now, the impact of variation orders on project cost and time was analyzed using secondary data obtained from the Client and the Contractor. The contracted completion time was compared with the actual completion time to find the delays in the implementation of the project. Similarly, contracted project cost was compared to the final project cost to determine the overall cost overrun.

The project had been categorized into major six parts as per its nature. The cost overrun of each part was also analyzed independently to determine the cost overrun of the corresponding part. This helped in determining the major impacted part by the variation orders.

Similarly, time overrun had resulted in cost increment to the Contractor and the Client. The Contractor was awarded with price escalation to overcome this extra cost incurred to it. Analysis of the price escalation awarded to the Contractor was calculated which, in fact, is the cost overrun to the project.

Preventing measures were explored from the analysis of major causes and their impacts in project cost and duration. Conclusions were made on which causes can be eliminated or reduced in severity by providing attention in initial phase of the project. These preventive measures can be useful in successful implementation of upcoming similar land pooling projects.

\section{RESULT AND DISCUSSION \\ Identification of Variation Orders in INLPP (II)}

Gravel sub base works was not initially included in contract which, by variation, has been introduced thorough out the road networks and double layer of the same has been introduced thorough out the pipe line networks.

Similarly, rigid pavement works has been also introduced in some sections of road by variation where initially asphalt concrete works was designed. Initially tick drain was designed with 127 tons of reinforcement but all the reinforcement has been removed by variation. Rework has been done for uplift of manhole covers, maintenance and addition of catch pits and maintenance and addition of sewage line. Those works were actually completed prior to this contract and was not included within the scope of this contract.

The deep tube well works is found to have incurred serious issue of change of drilling method.
From the study, it is found that rotary drilling technique was designed by consultant; however, the contractor has used DTH technique. The tube well is found to have failed and rework is done by the contractor to achieve required discharge of water. Also the depth of the deep tube well seems to have decreased by $4 \mathrm{~m}$ from $180 \mathrm{~m}$ to $174 \mathrm{~m}$ in actual field.

Another major variation in INLPP (II) is redesign of water supply pipelines. Complete water supply pipeline seems to have been redesigned after a dispute and stoppage of works by the users. New pipe sizes have been introduced, fittings and accessories required for those pipes have been added and the connection charge of those fittings inside the valve chambers has also been added. Similarly, DI pipes and fittings for inlet and outlet of overhead reservoir tanks have also been introduced by variation.

A 20 cubic meter sump well which was initially designed to collect water from deep tube well has been removed but the number of valve chambers has been increased from 127 to 149.At the same time, all the electrical works worth NPR. 23,00,000.00 have been removed. It included supply and installation of 2 pumps and a transformer in initial design.

\section{Causes of Variation Orders \\ Causes of Variation Order Impacting Project Completion Time}

From the questionnaire survey carried out with the respondents, "Conflict between the Contract Documents" has been ranked as the main cause of variation order impacting the project completion time. Contract documentation is the responsibility of the Consultant with RII 0.573 .

Similarly, "Change in design by the consultant/ Errors and Omissions in Design" has been ranked as 2 with RII 0.559. Other major cause, in overall, for variation order impacting project completion time is "Inadequate working drawing details". Origin of all the three major causes of variation order impacting project completion time is Consultant.

According to the informants, various additional works which was not included in bill of quantities were added. Gravel overlay which was already completed in previous contract but swept away before the present contract had to be added but it was not considered due to poor estimation. Pipeline network was completely redesigned which increased the cost by almost two times. Pipeline fittings, connection charge inside valve chambers, number of valve chambers, DI pipes and fittings were completely omitted due to poor estimation. Similarly, rigid pavement works was not considered in contract. Household sewage system and water supply system which had to be included in initial design, due to poor estimation and lack of coordination was omitted. 


\section{Impacts of Variation Orders}

Impacts of Variation Order on Cost Overrun

From the analysis of secondary data related to INLPP (II), the project is found to be developed into 6 different bills namely; General Items, Road Works, Deep Boring Works, Water Supply Pipe Networking
Works, Civil Works for Various Water Supply Components and Electrical \& Mechanical Works.

The estimated cost of each bill is as shown by pie chart in Figure 4.1.

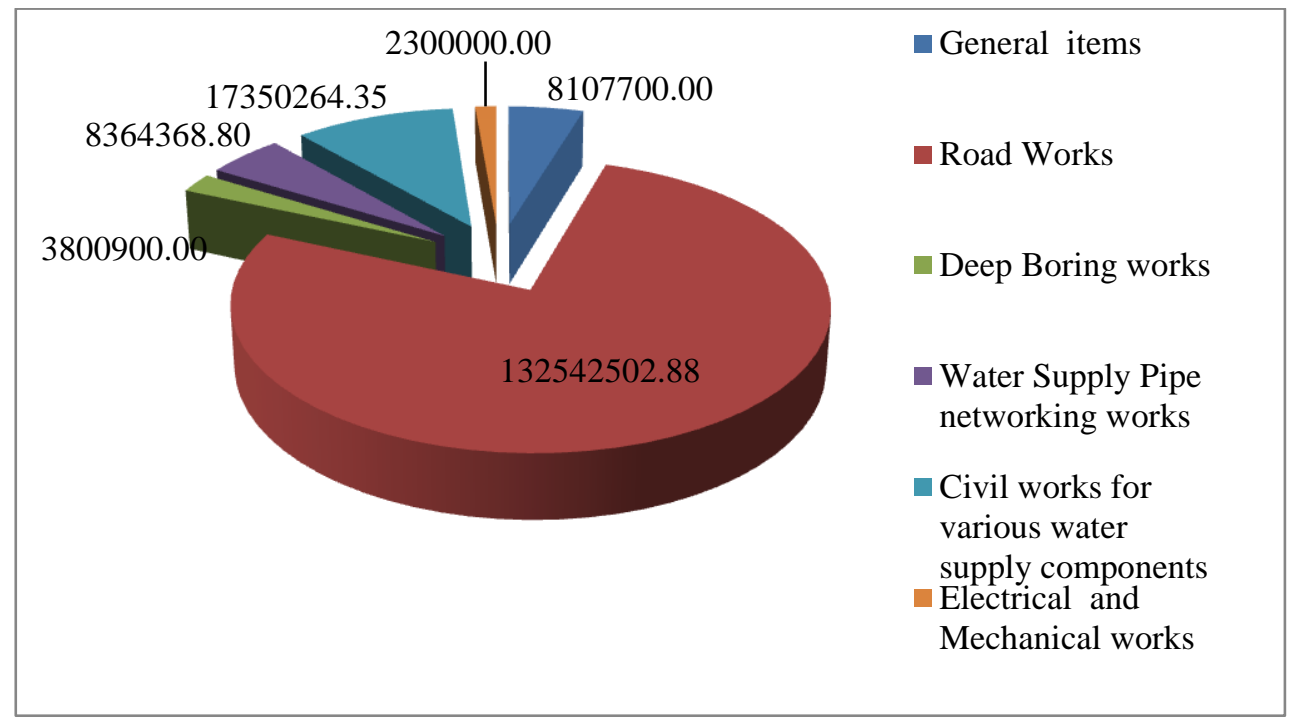

Figure 4. 1: Estimated Cost of Each Bills of Works

Similarly, the actual cost of each bill of works is as shown by pie chart in Figure 4.2.

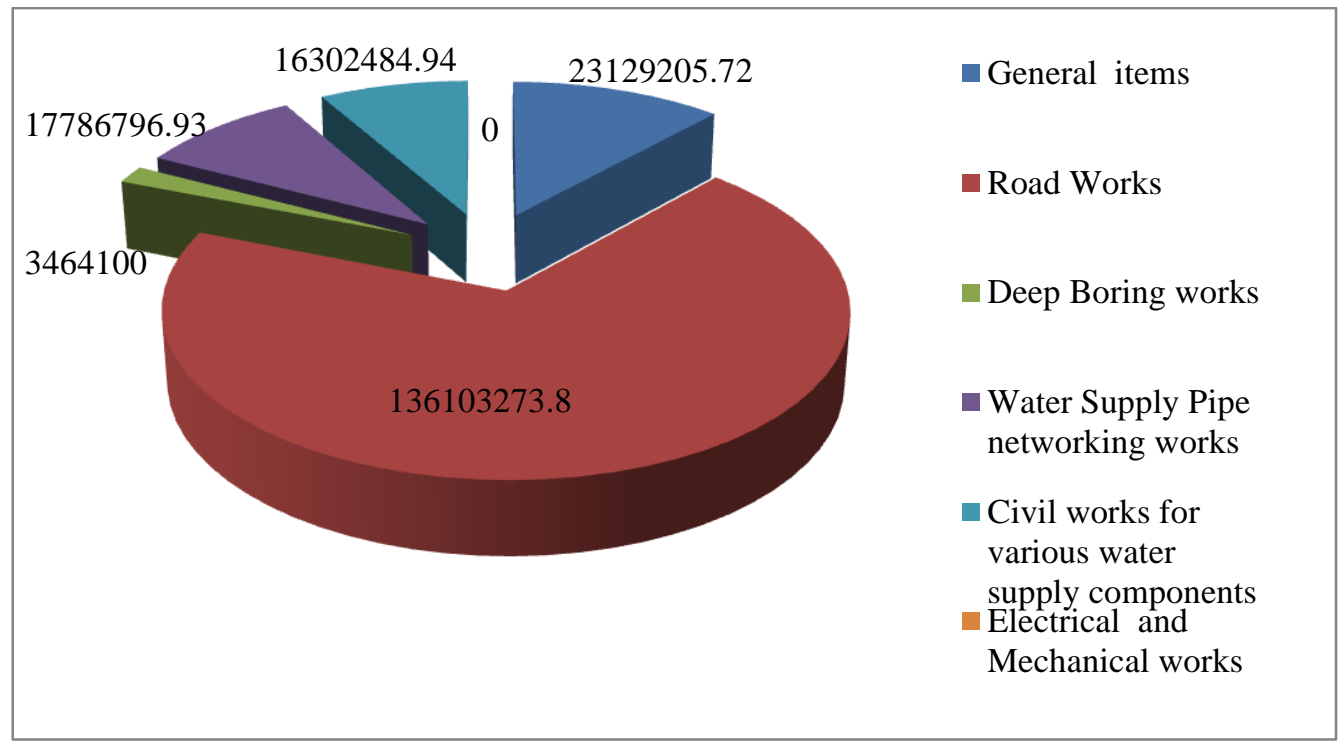

Figure 4. 2: Actual Cost of Each Bill of Works

The changes in total cost of each bill of works from estimated cost to actual cost are represented in Figure 4.3. 


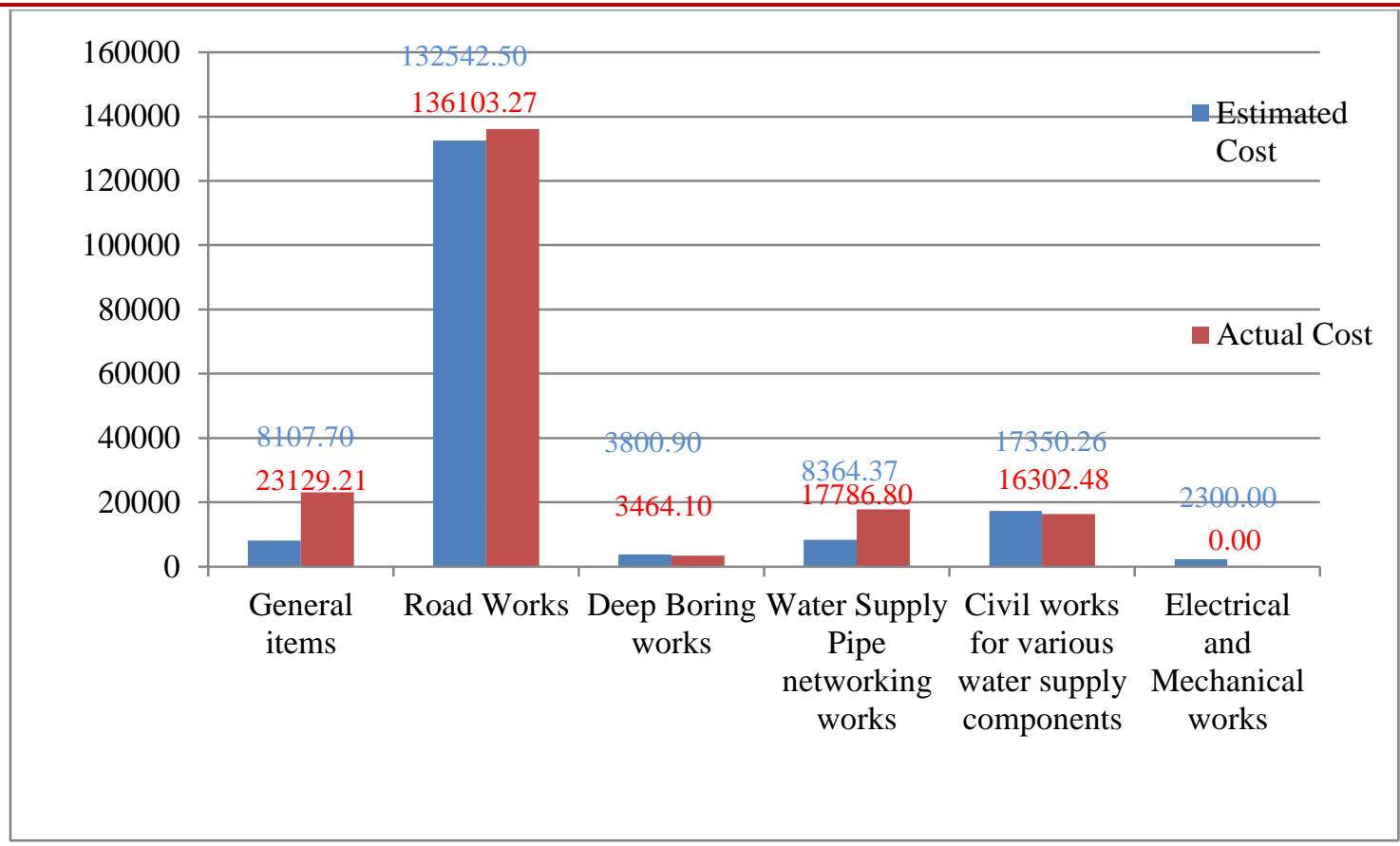

Figure 4. 3: Comparison of Estimated Cost and Actual Cost of Each Bill

\section{Impact of Variation Orders in "Bill I-I: General} Items"

From the study of each bill of the project works, a clearer image of the facts can be obtained. By analyzing "Bill I-I: General Items", it is known that the major parts under the general items are labor, materials and equipments. Labor has been increased by $69.82 \%$ above the estimate, material by $126.6 \%$ and equipments by $1262.5 \%$ which is also represented in Figure 4.4 .

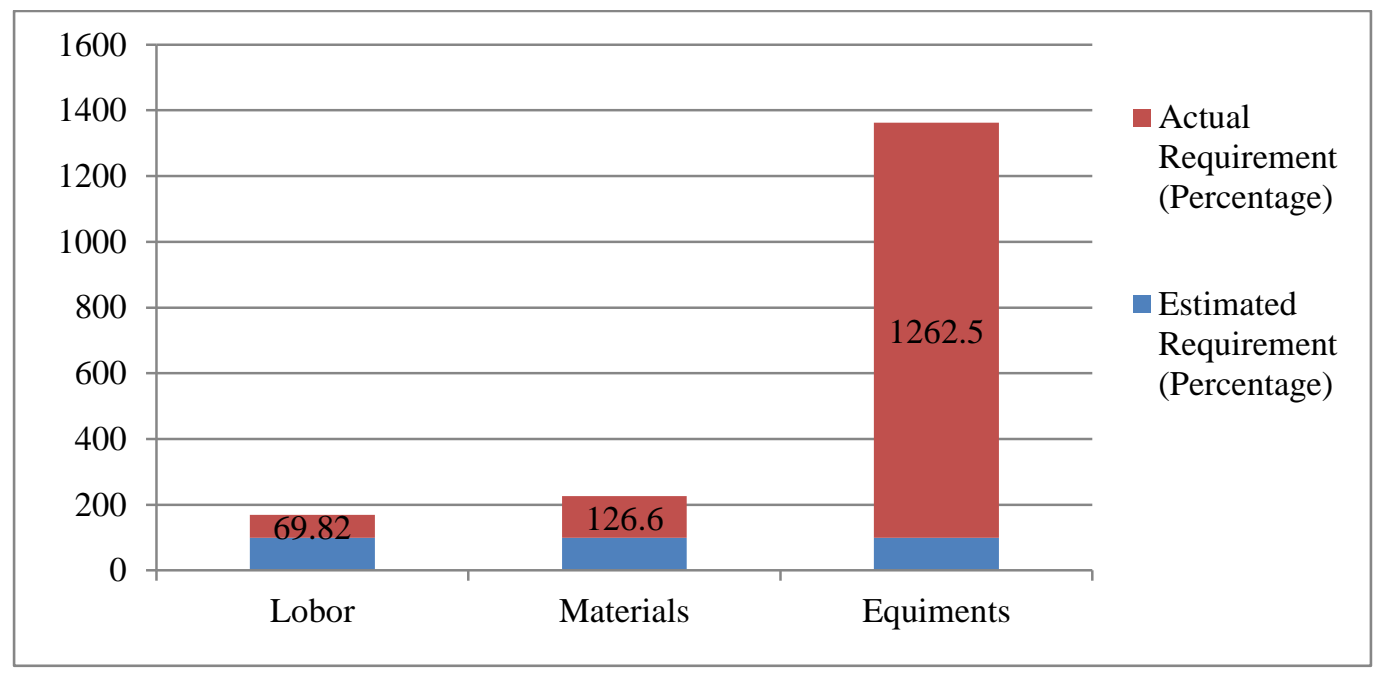

Figure 4. 4: Comparision of Cost Variation (Percentage) Under "Bill I-I: General Items"

Figure 4.5 shows the cost variation under "Bill I-I: General Items" in amount. It shows that the labor cost has increased by Rs 3,46,600, materials cost by Rs $76,63,140$ and equipments cost by Rs 70,51,076. 


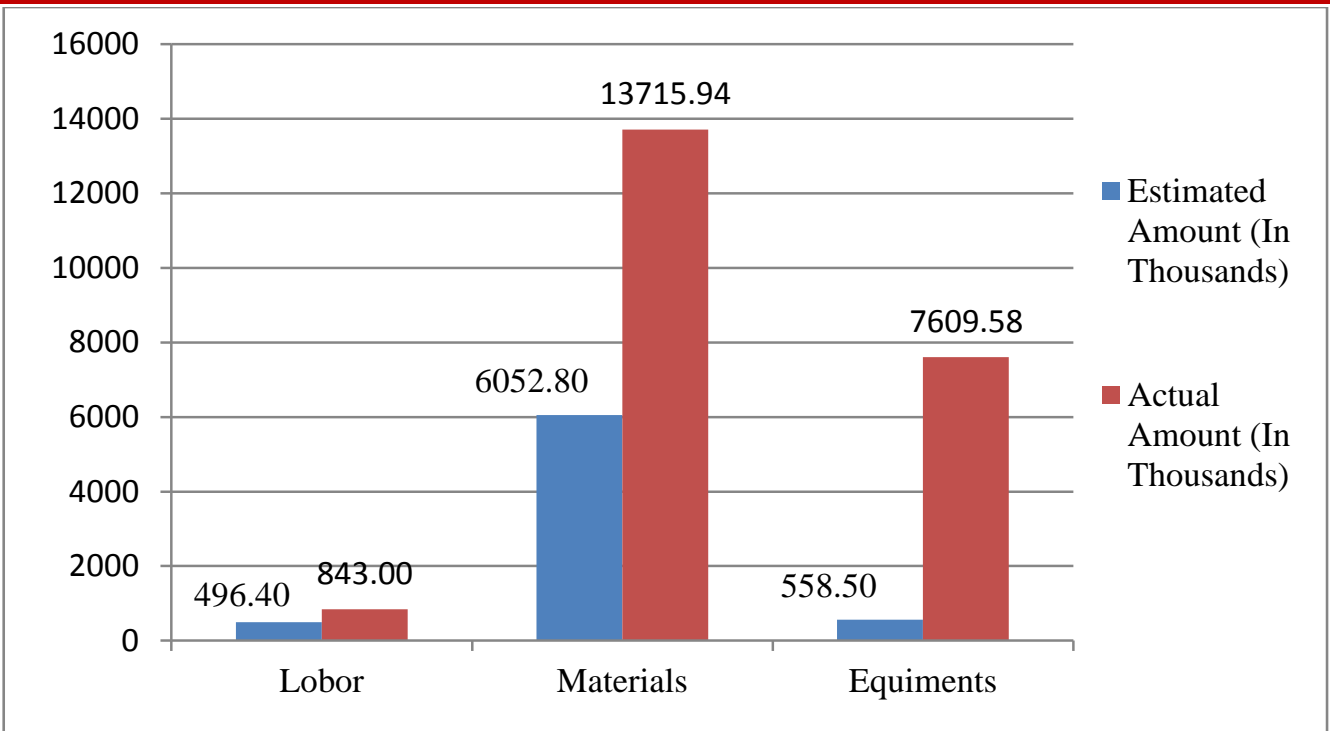

Figure 4. 5: Comparison of Cost Variation (Amount) Under "Bill I-I: General Items"

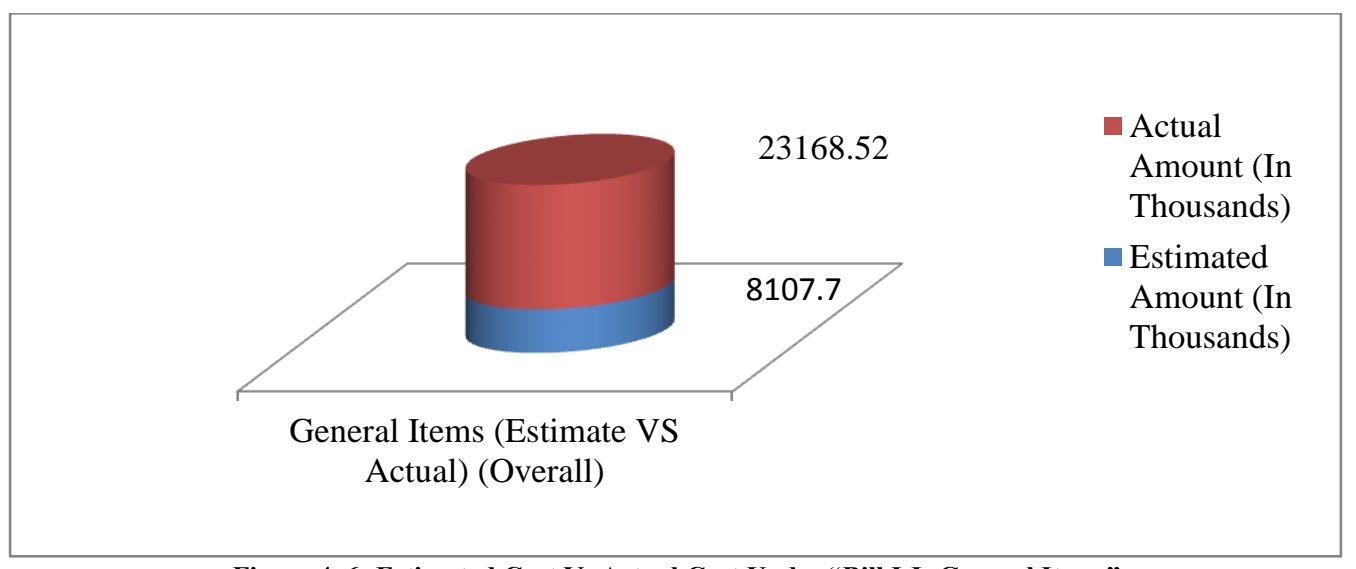

Figure 4. 6: Estimated Cost Vs Actual Cost Under "Bill I-I: General Items"

Impact of Variation Orders in "Bill I-II: Road Works"

From the study of "Bill I-II: Road Works", it is known that the major parts under the Road Works are road pavement works, civil works for construction of catch pit \& surface drain and Rigid Pavement. Road pavement works is decreased by NPR 14,03,444.22 below the estimate, civil works for construction of catch pit \& surface drain is decreased by NPR $89,86,924.31$.
It is also known that initially there was no any Rigid Pavement works in the contract. However, rigid pavement works of cost value NPR 13951121.31 is carried out by variation order.

Figure 4.7 illustrates the estimated cost and final cost of parts of works under Road Works.

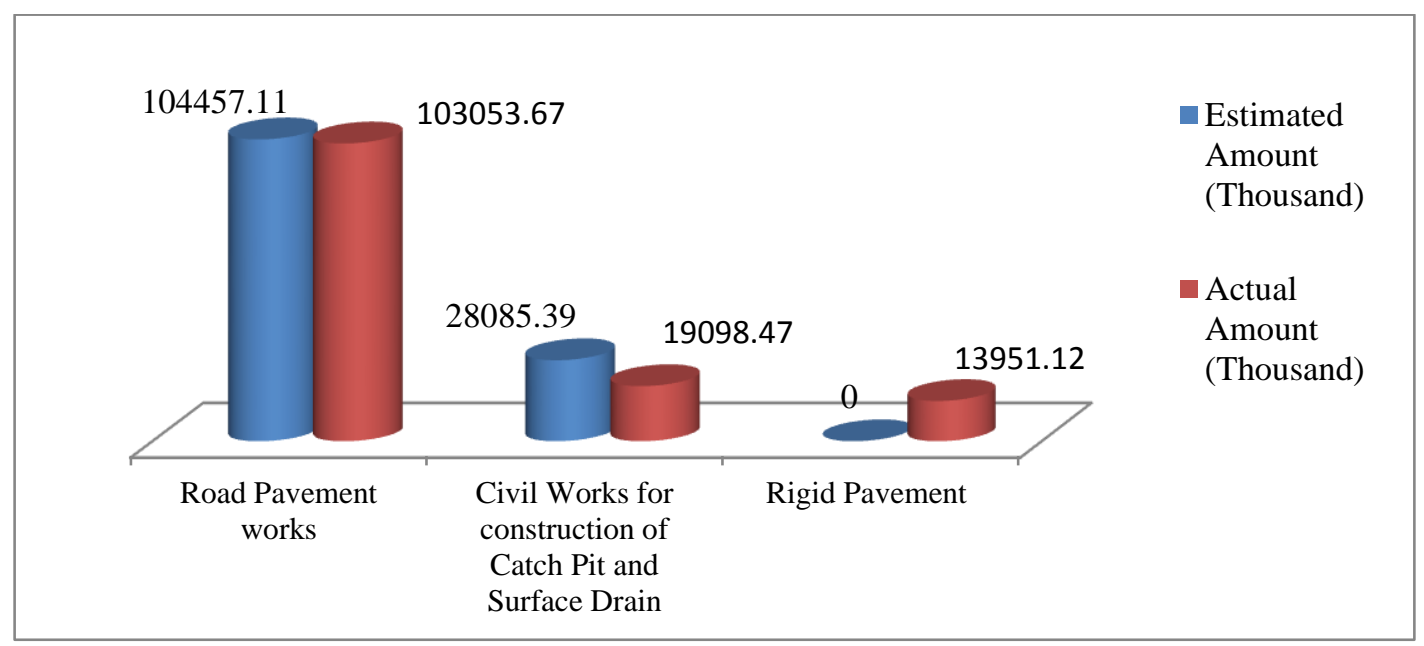

Figure 4. 7: Estimated cost Vs Final cost under Road Works 
Figure 4.8 shows that estimated total cost of road works and actual cost of the same.

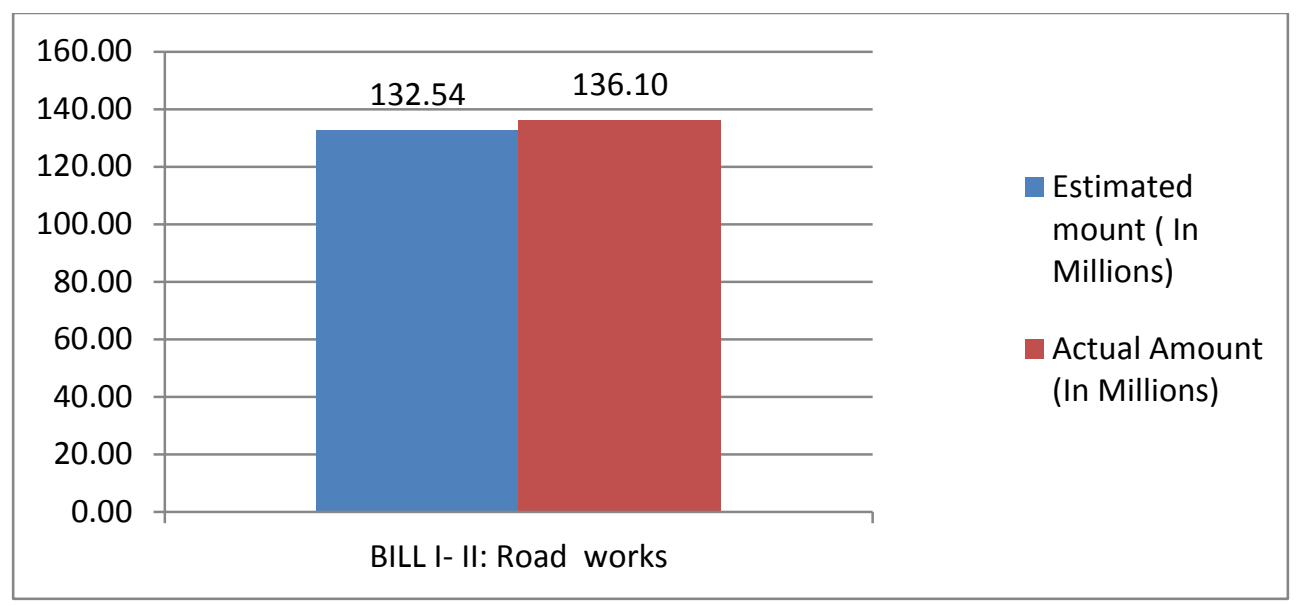

Figure 4. 8: Estimated cost Vs Final cost of Road Works

Similarly, Figure 4.9 shows the increment percentage of cost of road works.

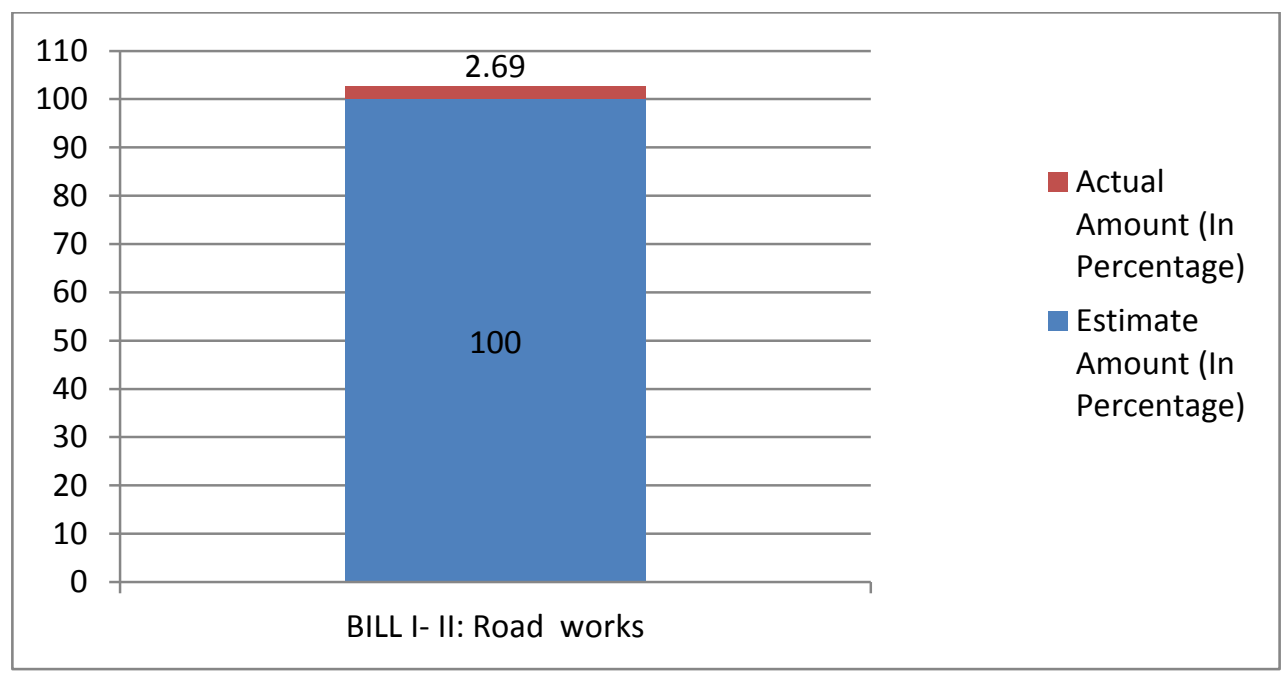

Figure 4. 9: Increment Percentage of Cost of Road Works

\section{Impact of Variation Orders in "Bill I-III: Deep Tube Well Works"}

From the study of "Bill I-III: Deep Tube Well Works", it is known that the major parts are drilling, development and pumping test, supply of well materials and supply and installation of submersible pump with standard accessories. Drilling, development and pumping test is decreased by NPR 72,000.00 below the estimate, supply of well materials and supply is decreased by NPR 2,22,800.00. Similarly, the amount of installation of submersible pump with standard accessories is also decreased in final bill by NPR $42,000.00$

Figure 4.10 illustrates the estimated cost and final cost of subcomponents under Bill I-III: Deep Tube Well Works. 


\section{Estimated VS Actual Amount (In Thousands)}

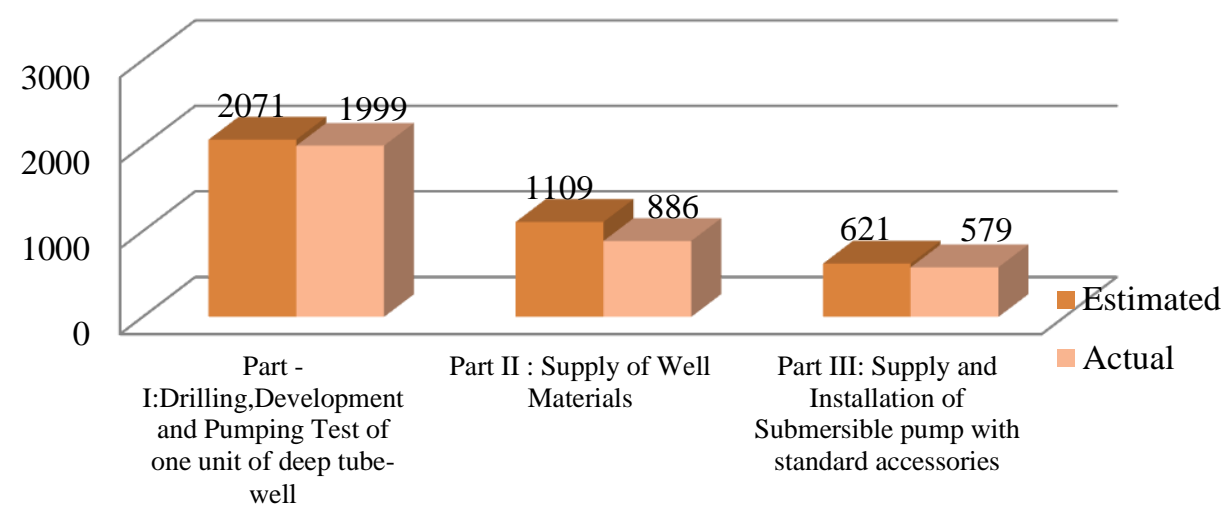

Figure 4. 10: Estimated cost Vs Final cost under Bill I-III: Deep Tube Well Works

Figure 4.11 shows that estimated total cost of deep tube well works and actual cost of the same.

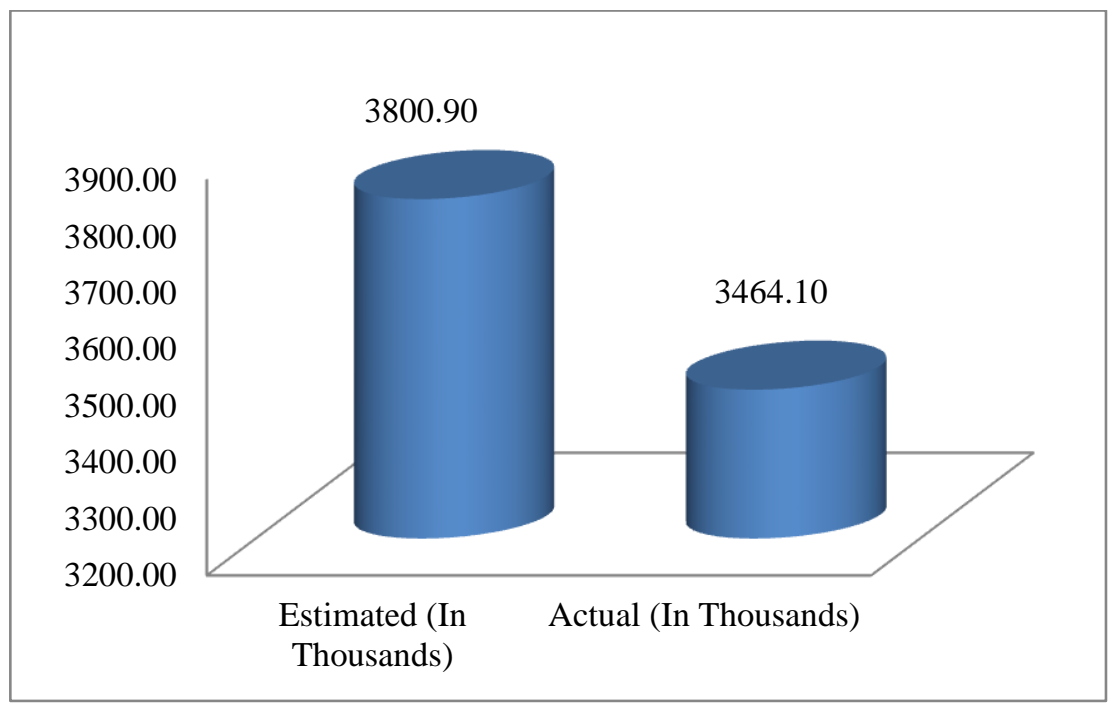

Figure 4. 11: Estimated cost Vs Final cost of Deep Tube Well Works

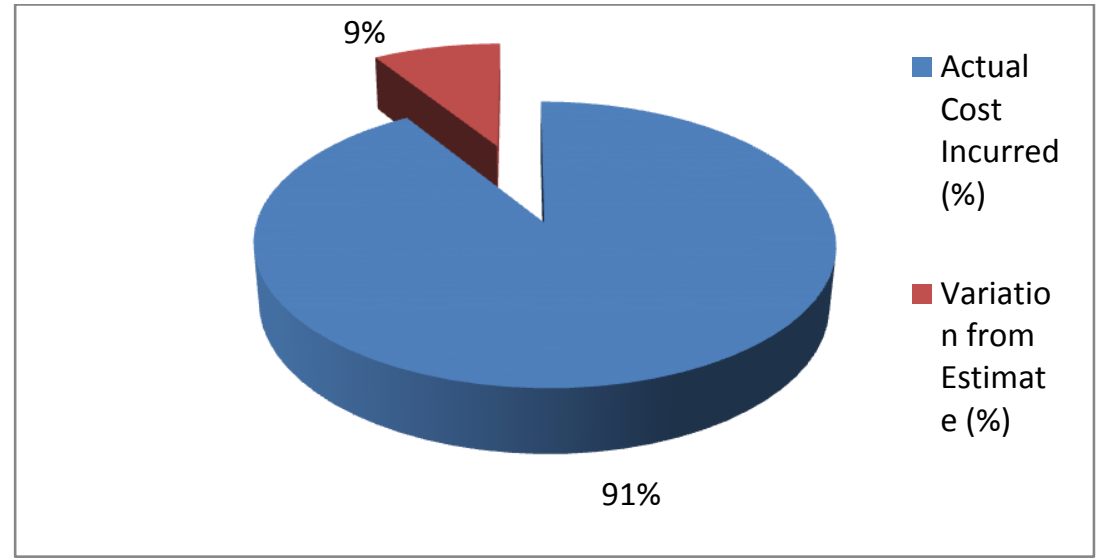

Figure 4. 12: Actual Cost Percentage of Deep Tube Well Works from Estimated Cost 
Impact of Variation Orders in "Bill I-IV: Water Supply Transmission and Distribution Line Pipe Networking Works"

From the study of "Bill I-IV: Water Supply

Transmission and Distribution Line Pipe Networking Works", it is known that the major parts are i) supply, laying and jointing of pipes, ii) Fittings and accessories, iii) Civil Works and iv) DI Pipes and Fittings.

Figure 4.13 illustrates the estimated cost and final cost of parts of works under Bill I-IV: Water Supply Transmission and Distribution Line Pipe Networking Works.

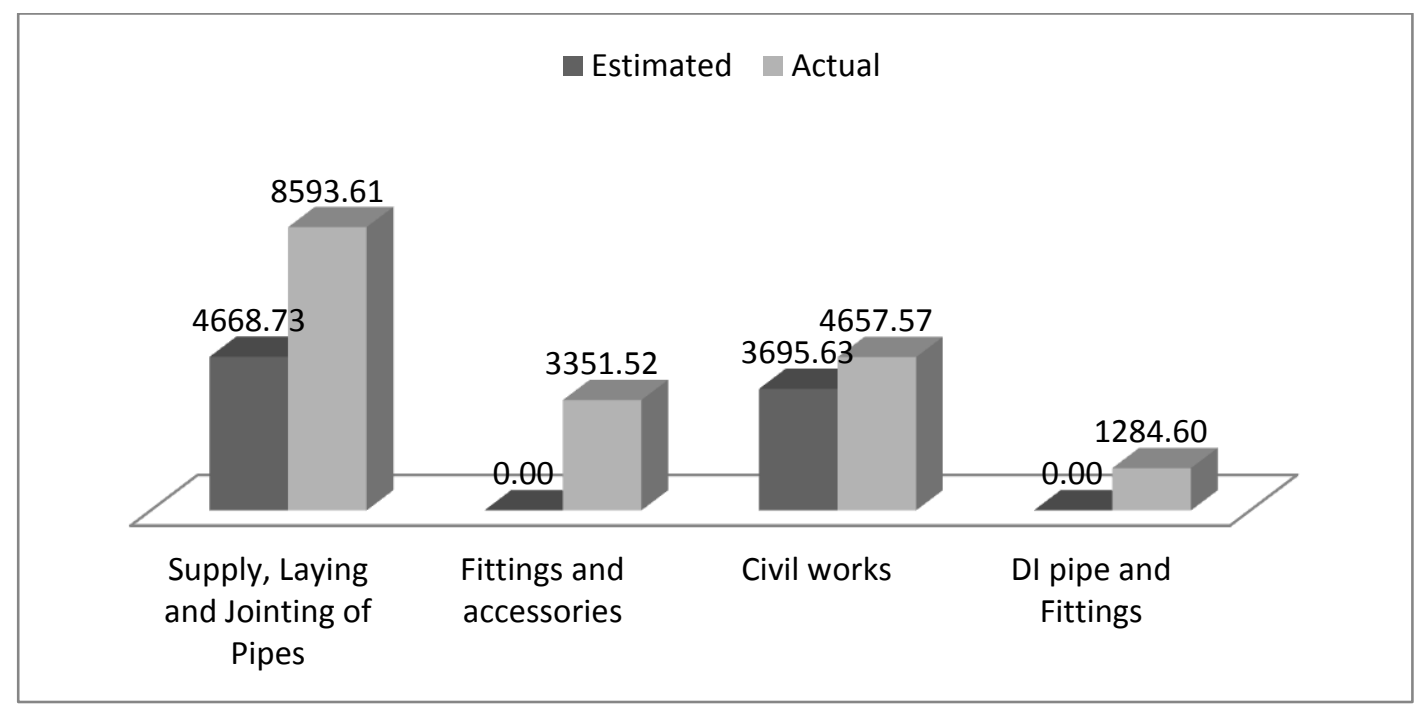

Figure 4. 13: Estimated cost Vs Final cost of parts of works under Bill I-IV: Water Supply Transmission and Distribution Line Pipe Networking Works

From the figure, it shows supply, laying and jointing of pipes is increased by NPR (In Thousands) 3924.97 and civil works is increased by NPR (In Thousands) 961.69. Similarly it also shows that initially there were no any items of fittings and accessories and DI pipe and Fittings. However, by the completion of project NPR (In Thousands) 3351.52 and NPR (In
Thousands) 1248.60 have been incurred to the project via variation.

The figure 4.14 illustrates the initial total amount and final actual amount under Bill I-IV: Water Supply Transmission and Distribution Line Pipe Networking Works. Similarly figure 4.18 illustrates the percentage of variation of the same.

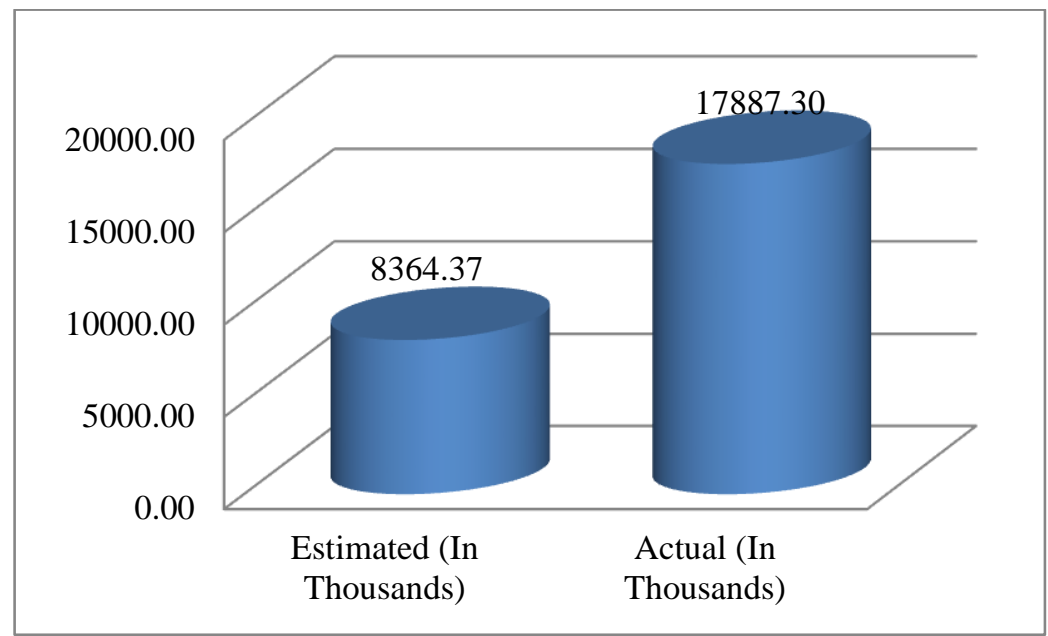

Figure 4. 14: Estimated Vs Actual Amount of Bill I-IV: Water Supply Transmission and Distribution Line Pipe Networking Works 


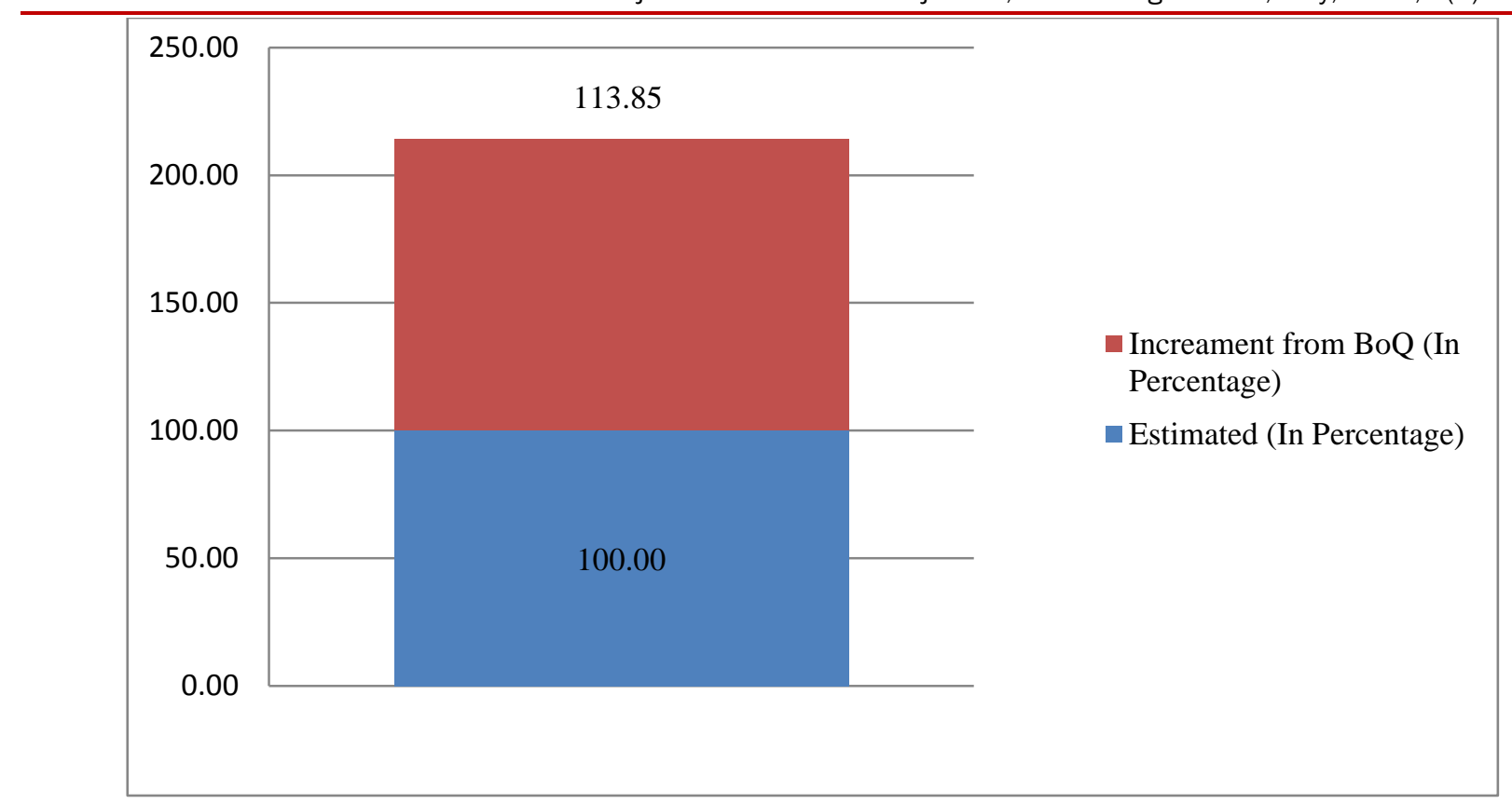

Figure 4. 15: Estimated Vs Actual Amount (In Percentage) of Bill I-IV: Water Supply Transmission and Distribution Line Pipe Networking Works

Impact of Variation Orders in "Bill I-V: Civil works for construction of various water supply components"

From the study of "Bill I-V: : Civil works for construction of various water supply components", it is known that the major parts are i) Construction of 150 cum Underground Reservoir Tank, ii) Construction of 100 cum Overhead Reservoir Tank, iii) Construction of 20 cum Sump Well, iv) Construction of Guard Quarter and v) Construction of Valve Chambers.

Figure 4.16 illustrates the estimated cost and final cost of parts of works under Bill I-V: Civil works for construction of various water supply components.
The figure shows Construction of 150 cum Underground Reservoir Tank is decreased by NPR (In Thousands) 272.12, Construction of 100 cum Overhead Reservoir Tank is increased by NPR (In Thousands) 10.49, Construction of Guard Quarter is decreased by NPR (In Thousands) 460.85 and Construction of Valve Chambers is increased by NPR (In Thousands) 1471.40. Similarly it also shows that initially there was a part of work under Construction of 20 cum Sump Well with estimated cost of NPR (In Thousands) 1549.70. However, by the completion of project Construction of 20 cum Sump Well has been omitted by variation.

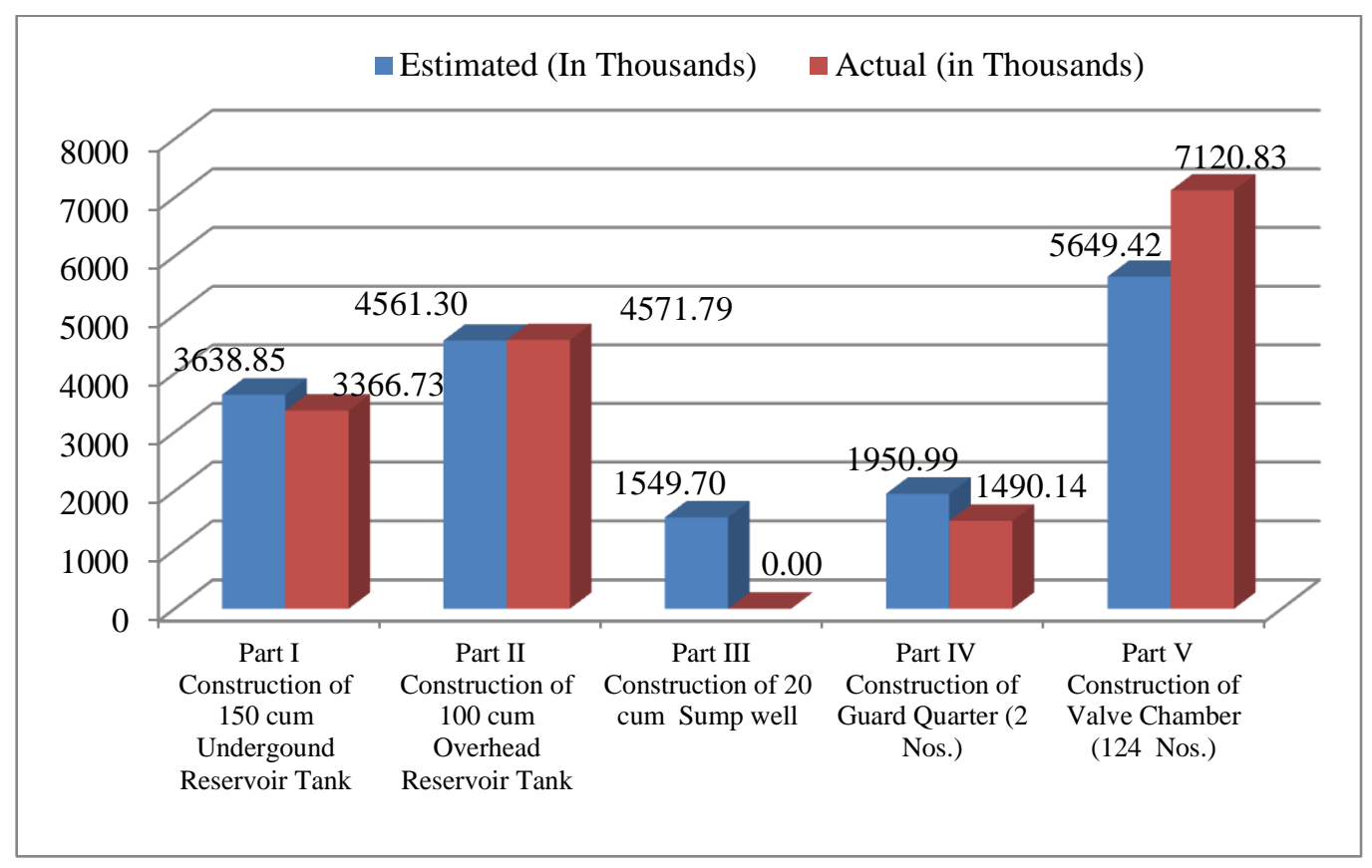

Figure 4. 16: Estimated cost Vs Final cost of parts of works under Bill I-V: Civil works for construction of various water supply components 
Figure 4.17 illustrates the actual cost incurred for works and the variation amount below the estimate under Bill I-V: Civil works for construction of various water supply components. The figure shows that the total cost of Civil Works for construction of various water supply components has been decreased by NPR (In Thousands) 800.78. The total estimate of works is NPR (In Thousands) 17,350.25. From this, it is known that the works has been completed with cost $4.62 \%$ below the estimate.

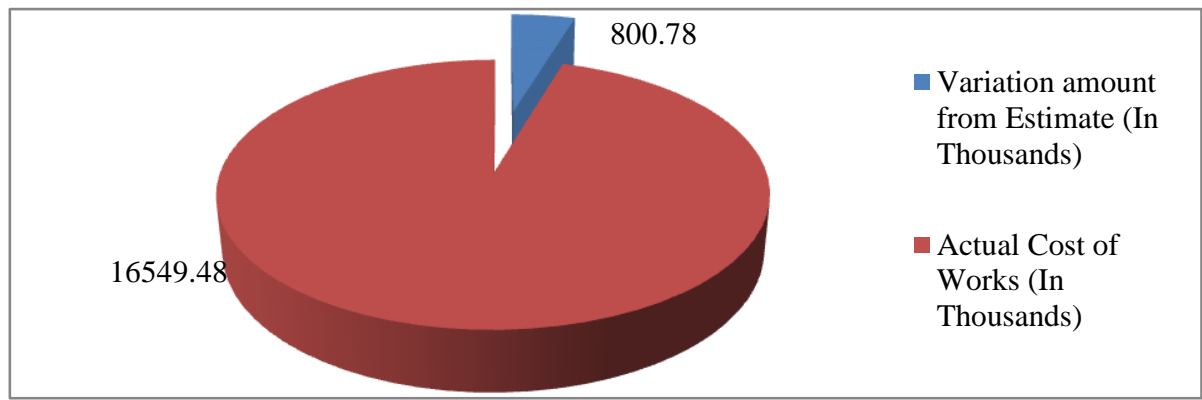

Figure 4. 17: Fraction of Actual Cost and Variation from Estimate amount under Bill I-V: Civil works for construction of various water supply components

\section{Impact of Variation Orders in "Bill I-VI: Electrical and Mechanical Works" \\ The works under this part included i)} Providing \& fitting submersible Shakti pump $50 \mathrm{HP}$ (QF 160-3B) including all complete panel board with civil works \& accessories, ii) Providing \& fitting submersible Shakti pump 15 HP (QF 160-15) including all complete panel board with civil works \& accessories and iii) Providing \& fitting 50 KVA Transformer including all complete panel board with civil works \& accessories. The total estimated amount under the bill is NPR 23,00,000.00. However, all the works are removed via variation.

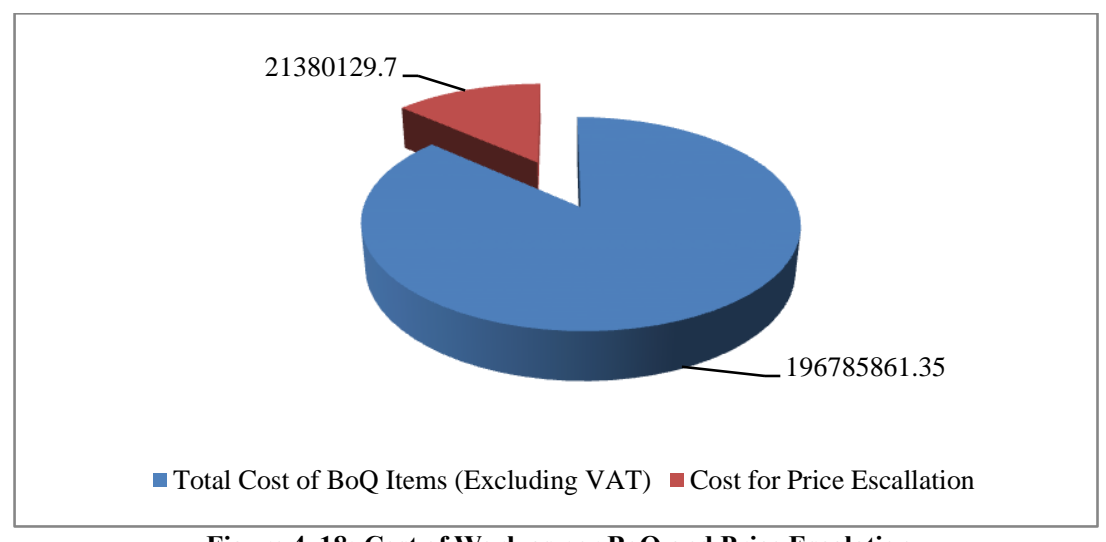

Figure 4. 18: Cost of Work as per BoQ and Price Escalation

Similarly the major impact of time overrun on indirect cost overrun are due to i) Interest during Construction and ii) Increase in Cost of Successive Contract. Since the entire required budget for the project is obtained from the landowners by selling the sales plot, the Client is not entitled with Interest during Construction.
Similarly, Increase in Cost of Successive Contract is another major impact of time overrun on indirect cost. Polling and HT Line Extension Works is another contract the project intends to start. The initial estimated cost of the contract was NPR 2,97,44,347.91 (With VAT). However, estimate of the contract has been readjusted and the final estimate is NPR $3,47,88,711.00$. This shows the increment of $16.96 \%$ in upcoming contract.

Table: 4.1 : Increase in Cost of Successive Contract

\begin{tabular}{|l|l|l|l|l|l|}
\hline S/N & $\begin{array}{l}\text { Name of } \\
\text { Upcoming } \\
\text { Contract }\end{array}$ & $\begin{array}{l}\text { Initial Estimated Cost } \\
\text { (With VAT) (NPR) }\end{array}$ & $\begin{array}{l}\text { Updated Estimated } \\
\text { Cost (With VAT) (NPR) }\end{array}$ & $\begin{array}{l}\text { Difference } \\
\text { (NPR) }\end{array}$ & $\begin{array}{l}\text { Percentage } \\
\text { Increment } \\
(\%)\end{array}$ \\
\hline 1 & $\begin{array}{l}\text { Polling and HT } \\
\text { Line Extension } \\
\text { Works }\end{array}$ & $2,97,44,347.91$ & $3,47,88,711.00$ & $50,44,363.09$ & 16.96 \\
\hline
\end{tabular}




\section{Time Overrun in Ichangu Narayan (Raniban) Land} Pooling Project (Phase II)

The details of time overrun of Ichangu Narayan (Raniban) Land Pooling Project (Phase II) is represented in figure 4.23 and figure 4.2.

From the study of contract agreement date, work start date, intended work completion date, time extension letter issued by the Client and completion date it is observed that the project agreement was made at 2014 December $16(2071 / 09 / 01)$, work start date was 2014 December 29 with intended completion date of 2016 June 26. However the project is competed at 2018 June 23 which shows the project has suffered from 727 days of time extension which is $133.39 \%$ above the contract duration.

Table 4.2: Intended Completion Time Vs Actual Completion Time

\begin{tabular}{|l|l|l|l|l|l|l|l|}
\hline S/N & $\begin{array}{l}\text { Agreement } \\
\text { Date }\end{array}$ & $\begin{array}{l}\text { Work Start } \\
\text { Date }\end{array}$ & $\begin{array}{l}\text { Intended } \\
\text { Completion } \\
\text { Date }\end{array}$ & $\begin{array}{l}\text { Actual } \\
\text { Completion } \\
\text { date }\end{array}$ & $\begin{array}{l}\text { No of } \\
\text { Delay } \\
\text { Days }\end{array}$ & $\begin{array}{l}\text { Extension of } \\
\text { Time in } \\
\text { Percentage }\end{array}$ & Remarks \\
\hline 1 & $2014 / 12 / 16$ & $2014 / 12 / 29$ & $2016 / 06 / 26$ & $2018 / 06 / 23$ & 727 & $133.39 \%$ & \\
\hline
\end{tabular}

\section{Preventing Measures for Variation Orders}

Study of INLPP (II) has provided the information about the causes and impacts of variation orders relating to time extension and cost overrun. Analysis of the results of the study helped in preparing the preventing measures for variation orders.

Study of INLPP (II) project shows that the main causes of variation orders are not beyond the control of major stakeholders of the project. Most of the major causes are originated from Consultant and the Client. The causes originated from the others are found to have minor impact according to questionnaire survey. Preventing measures for similar future projects can be developed from the analysis of causes of variation orders and their impacts in project cost and time.
The preventing measures can be categorized into three groups according to the origin of the causes of variation orders.

\section{Client Related Preventing Measures}

Client is an origin of variation orders. The variation orders originated by Client are generally controllable. Preventing measures taken in time can eliminate or reduce those variation orders.

The preventing measures are control mechanism of causes of variation orders. Preventing measures of variation orders originated from clients for land pooling projects are as follows:

Table- 4. 1: Preventing Measures for Variation Orders from Client Impacting Project Completion Time

\begin{tabular}{|l|l|l|l|}
\hline S/N & $\begin{array}{l}\text { Causes of Variation Order } \\
\text { Impacting Project Duration }\end{array}$ & $\mathbf{R I I}(\mathbf{C l})=$ & Preventing Measures \\
\cline { 3 - 4 } & Change of schedule & 0.533 & $\mathbf{W}(\mathbf{N})$ \\
\hline 2 & $\begin{array}{l}\text { Client's financial problems/ Delay in } \\
\text { Payment of Bill }\end{array}$ & 0.502 & $\begin{array}{l}\text { The client should set targets for milestones of } \\
\text { projects and prepares and remain stuck to the } \\
\text { schedule. }\end{array}$ \\
\hline 3 & $\begin{array}{l}\text { Impediment in prompt decision } \\
\text { making process }\end{array}$ & 0.492 & $\begin{array}{l}\text { The client should prepare a good plan of } \\
\text { maintaining and allocating budget in time. }\end{array}$ \\
\hline
\end{tabular}

Table- 4. 2: Preventing Measures for Variation Orders Originating from Client Impacting Project Cost

\begin{tabular}{|l|l|l|l|}
\hline S/N & $\begin{array}{l}\text { Causes of Variation Orders } \\
\text { Impacting Project Cost }\end{array}$ & $\mathbf{R I I}=\sum \mathbf{W} /\left(\mathbf{A}^{*} \mathbf{N}\right)$ & Preventing Measures \\
\hline 1 & Additional Work & 0.547 & $\begin{array}{l}\text { The client should prepare a clear vision about the extent } \\
\text { of the project and scope of the works within the extent } \\
\text { of the project. }\end{array}$ \\
\hline 2 & $\begin{array}{l}\text { Client's financial problems/ } \\
\text { Delay in Payment of Bill }\end{array}$ & 0.496 & $\begin{array}{l}\text { The client should prepare a good plan of maintaining } \\
\text { and allocating budget in time. }\end{array}$ \\
\hline
\end{tabular}

\section{Consultant Related Preventing Measures}

Consultants, if provide proper attention, can, in most cases, prevent variation orders. Preventing measures to be taken by consultants in land pooling projects developed from the study of causes of variation orders in INLPP (II) are as follows: 
Aananda Raj Pokharel \& Buddhi Raj Joshi., Saudi J Eng Technol, May, 2020; 5(5): 203-230

\begin{tabular}{|l|l|l|l|}
\hline \multicolumn{2}{|c|}{ Table 4. 3: Preventing Measures for Variation Orders Originating from Consultant Impacting Project Cost } \\
\hline S/N & $\begin{array}{l}\text { Causes of Variation Orders } \\
\text { Impacting Project Cost }\end{array}$ & $\begin{array}{l}\text { RII= } \\
\sum \mathbf{W} /(\mathbf{A} * \mathbf{N})\end{array}$ & Preventing Measures \\
\hline 1 & $\begin{array}{l}\text { Lack of Cost Planning/ } \\
\text { Monitoring during pre and } \\
\text { post contract Stage }\end{array}$ & 0.541 & $\begin{array}{l}\text { The Consultant should provide proper attention in availability, } \\
\text { allocation and utilization of budget. }\end{array}$ \\
\hline 3 & $\begin{array}{l}\text { Poor Estimation of Original } \\
\text { Cost }\end{array}$ & 0.533 & $\begin{array}{l}\text { Detailed estimate of cost should be done at the time of } \\
\text { preparation of bidding documents. }\end{array}$ \\
\hline 4 & $\begin{array}{l}\text { Design Complexity } \\
\text { Time of Tender }\end{array}$ & $\begin{array}{l}\text { As much as possible avoid complex design, consider seriously } \\
\text { the build ability in the design. Build in adequate flexibility in } \\
\text { design to respond more proactively to imminent change as per } \\
\text { site requirements. }\end{array}$ \\
\hline 5 & $\begin{array}{l}\text { Change in design } \\
\text { Detailed and comprehensive site investigation should be done } \\
\text { at the design phase and complete working drawings should be } \\
\text { prepared before tendering to avoid delays and variations due to } \\
\text { change in design during project implementation phase. }\end{array}$ \\
\hline
\end{tabular}

Table 4. 4: Preventing Measures for Variation Orders Originated From Consultant Impacting Project Completion Time

\begin{tabular}{|c|c|c|c|}
\hline $\mathbf{S} / \mathbf{N}$ & $\begin{array}{l}\text { Causes of Variation } \\
\text { Order Impacting } \\
\text { Project Duration }\end{array}$ & $\frac{\mathbf{R I I}(\mathbf{C o n})=}{\sum \mathbf{W} /(\mathbf{A} * \mathbf{N})}$ & Preventing Measures \\
\hline 1 & $\begin{array}{l}\text { Conflicts between } \\
\text { contract documents }\end{array}$ & 0.573 & \multirow{2}{*}{$\begin{array}{l}\text { Continuous coordination and direct communication with Client and } \\
\text { end users is recommended which will eliminate conflict between the } \\
\text { contract documents, design discrepancies and errors as well as } \\
\text { omissions in design and also provide opportunity for professionals } \\
\text { to review the contract documents thoroughly. }\end{array}$} \\
\hline 2 & $\begin{array}{l}\text { Change in design by the } \\
\text { consultant/ Errors and } \\
\text { omissions in design }\end{array}$ & 0.559 & \\
\hline 3 & $\begin{array}{l}\text { Inadequate working } \\
\text { drawing details }\end{array}$ & 0.542 & $\begin{array}{l}\text { Provide comprehensive information required for easier interpretation } \\
\text { of the drawings and setting out of the works. Specifications should } \\
\text { also be standardized as much as possible for ease understanding by } \\
\text { the project participants. }\end{array}$ \\
\hline 4 & $\begin{array}{l}\text { Inadequate scope of } \\
\text { work for contractor }\end{array}$ & 0.531 & $\begin{array}{l}\text { The consultant should pay proper attention on scope of works } \\
\text { defined by Client and incorporate all the extent and scope of works } \\
\text { in contracting process. }\end{array}$ \\
\hline 5 & $\begin{array}{l}\text { Lack of coordination/ } \\
\text { communication }\end{array}$ & 0.525 & $\begin{array}{l}\text { Continuous coordination and direct communication with Client and } \\
\text { end users is recommended which will eliminate conflict between the } \\
\text { contract documents, design discrepancies and errors as well as } \\
\text { omissions in design and also provide opportunity for professionals } \\
\text { to review the contract documents thoroughly. }\end{array}$ \\
\hline 6 & $\begin{array}{l}\text { Non-compliant design } \\
\text { with government } \\
\text { regulations }\end{array}$ & 0.524 & $\begin{array}{l}\text { Provide adequate attention in government rules and by laws to } \\
\text { ensure that the design remains within the rules and by laws. }\end{array}$ \\
\hline 7 & $\begin{array}{l}\text { Consultant's lack of } \\
\text { judgment and } \\
\text { experience }\end{array}$ & 0.507 & $\begin{array}{l}\text { Consultant should hire experienced experts of related field in design } \\
\text { and implementation phase both. }\end{array}$ \\
\hline 8 & Design complexity & 0.497 & $\begin{array}{l}\text { As much as possible avoid complex design, consider seriously the } \\
\text { build ability in the design. Build in adequate flexibility in design to } \\
\text { respond more proactively to imminent change as per site } \\
\text { requirements. }\end{array}$ \\
\hline
\end{tabular}

\section{Contractor Related Preventing Measures}

Contractor is the major stakeholder who actually materializes the project in real field. Preventing measures taken by contractor in correct time to avoid or reduce variation orders can significantly affect the project positively in its successful completion. The following preventing measures have been developed from the study of causes of variation orders in INLPP (II): 
Aananda Raj Pokharel \& Buddhi Raj Joshi., Saudi J Eng Technol, May, 2020; 5(5): 203-230

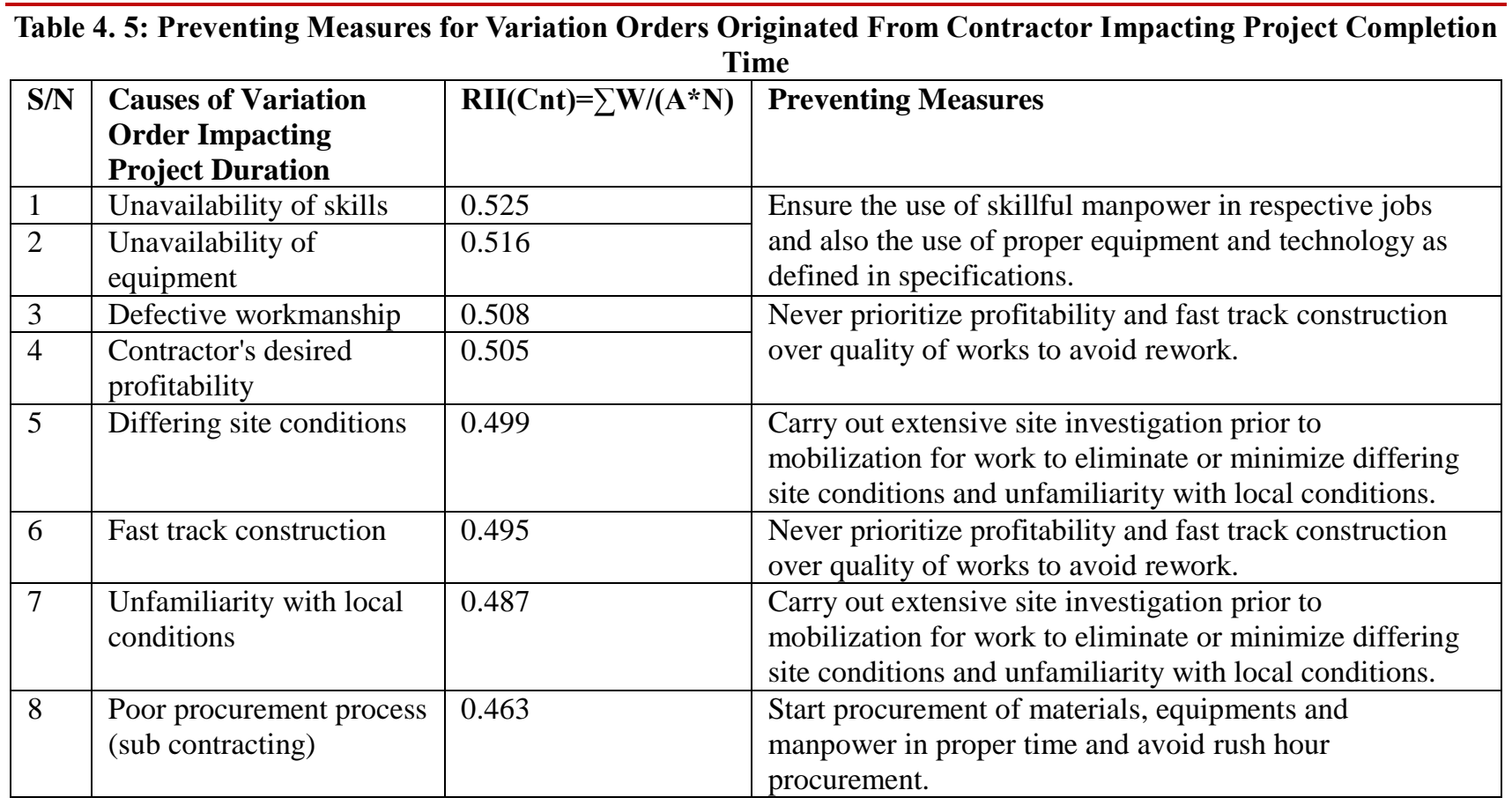

Table 4. 6: Preventing Measures for Causes of Variation Orders from Contractor Impacting Project Cost

\begin{tabular}{|l|l|l|l|}
\hline $\begin{array}{l}\text { S/ } \\
\mathbf{N}\end{array}$ & $\begin{array}{l}\text { Causes of Variation Orders } \\
\text { Impacting Project Cost }\end{array}$ & $\mathbf{R I I}=\sum \mathbf{W} /\left(\mathbf{A}^{*} \mathbf{N}\right)$ & Preventing Measures \\
\hline 1 & $\begin{array}{l}\text { Poor Project Site Management/ } \\
\text { Poor Cost Control }\end{array}$ & 0.513 & $\begin{array}{l}\text { Deploy sufficient and experienced supervision, } \\
\text { monitoring and control team to control defective } \\
\text { workmanship. }\end{array}$ \\
\hline 2 & Defective workmanship (Rework) & 0.51 & $\begin{array}{l}\text { Never prioritize profitability and fast track construction } \\
\text { over quality of works to avoid rework. }\end{array}$ \\
\hline 3 & $\begin{array}{l}\text { Unfamiliarity with local } \\
\text { conditions (e.g. Public } \\
\text { Disturbances, working site not } \\
\text { clear, etc.) }\end{array}$ & 0.492 & $\begin{array}{l}\text { Carry out extensive site investigation prior to } \\
\text { mobilization for work to eliminate or minimize } \\
\text { differing site conditions and unfamiliarity with local } \\
\text { conditions. }\end{array}$ \\
\hline 4 & $\begin{array}{l}\text { Fast track construction } \\
\text { Never prioritize profitability and fast track construction } \\
\text { over quality of works to avoid rework. }\end{array}$ \\
\hline
\end{tabular}

ANNEX-A

Data Analysis

Table 4. 7: Causes of Variation Orders Impacting Project Completion Time (Overall)

\begin{tabular}{|l|l|l|l|l|l|}
\hline S/N & Causes of Variation Order Impacting Project Duration & $\begin{array}{l}\text { Origin/ } \\
\text { Source }\end{array}$ & $\begin{array}{l}\sum \mathbf{W}=\mathbf{R}=\sum \mathbf{W} / \\
(\mathbf{A} * \mathbf{N})\end{array}$ & $\mathbf{R a n k}$ \\
\hline 1 & Change of plans or scope & Client & 199 & 0.390 & 24 \\
\hline 2 & Change of schedule & Client & 272 & 0.533 & 4 \\
\hline 3 & Client's financial problems/ Delay in Payment of Bill & Client & 256 & 0.502 & 13 \\
\hline 4 & Impediment in prompt decision making process & Client & 251 & 0.492 & 17 \\
\hline 5 & $\begin{array}{l}\text { Change in design by the consultant/ Errors and omissions in } \\
\text { design }\end{array}$ & Consultant & 285 & 0.559 & 2 \\
\hline 6 & Conflicts between contract documents & Consultant & 292 & 0.573 & 1 \\
\hline 7 & Inadequate scope of work for contractor & Consultant & 268 & 0.531 & 5 \\
\hline 8 & Lack of coordination/ communication & Consultant & 268 & 0.525 & 6 \\
\hline 9 & Design complexity & Consultant & 251 & 0.497 & 15 \\
\hline 10 & Inadequate working drawing details & Consultant & 271 & 0.542 & 3 \\
\hline 11 & Consultant's lack of judgment and experience & Consultant & 246 & 0.507 & 11 \\
\hline 12 & Non-compliant design with government regulations & Consultant & 267 & 0.524 & 8 \\
\hline 13 & Unavailability of equipment & Contractor & 263 & 0.516 & 9 \\
\hline 14 & Unavailability of skills & Contractor & 265 & 0.525 & 6 \\
\hline 15 & Contractor's desired profitability & Contractor & 255 & 0.505 & 12 \\
\hline
\end{tabular}


Aananda Raj Pokharel \& Buddhi Raj Joshi., Saudi J Eng Technol, May, 2020; 5(5): 203-230

\begin{tabular}{|l|l|l|l|l|l|}
\hline \hline 16 & Differing site conditions & Contractor & 252 & 0.499 & 14 \\
\hline 17 & Defective workmanship & Contractor & 254 & 0.508 & 10 \\
\hline 18 & Unfamiliarity with local conditions & Contractor & 241 & 0.487 & 18 \\
\hline 19 & Fast track construction & Contractor & 250 & 0.495 & 16 \\
\hline 20 & Poor procurement/ subcontracting process & Contractor & 236 & 0.463 & 21 \\
\hline 21 & Weather conditions & Others & 234 & 0.459 & 22 \\
\hline 22 & Health and safety considerations & Others & 240 & 0.480 & 20 \\
\hline 23 & Change in economic conditions & Others & 232 & 0.459 & 22 \\
\hline 24 & Unforeseen problems & Others & 247 & 0.484 & 19 \\
\hline
\end{tabular}

From analysis of causes of variation order impacting project completion time originated from the Client, the major causes are found to be "Changes of Schedule", "Client's Financial Problems/ Delay in
Payment of Bill" and "Impediment in Prompt Decision Making Process". They hold rank 4, 13 and 17 respectively in overall ranking.

Table 4. 8: Causes of Variation Orders Originated From Client Impacting Project Completion Time

\begin{tabular}{|l|l|l|l|l|}
\hline S/N & Causes of Variation Order Impacting Project Duration & $\sum \mathbf{W}=$ & $\begin{array}{l}\mathbf{R I I}(\mathbf{C l})= \\
\sum \mathbf{W} /\left(\mathbf{A}^{* \mathbf{N}}\right)\end{array}$ & Rank (RI) \\
\hline 1 & Change of plans or scope & 199 & 0.390 & 4 \\
\hline 2 & Change of schedule & 272 & 0.533 & 1 \\
\hline 3 & Client's financial problems/ Delay in Payment of Bill & 256 & 0.502 & 2 \\
\hline 4 & Impediment in prompt decision making process & 251 & 0.492 & 3 \\
\hline
\end{tabular}

From analysis of causes of variation order impacting project completion time originated from the Consultant, the major causes are found to be "Conflict between Contract Documents", "Changes in Design by the Consultant/ Errors and omissions in design" and "Inadequate working Drawing Details". They hold rank 1,2 and 3 respectively in overall ranking also.

Table 4. 9: Causes of Variation Orders from Consultant Impacting Project Completion Time

\begin{tabular}{|l|l|l|l|l|}
\hline S/N & Causes of Variation Order Impacting Project Duration & $\sum \mathbf{W}=$ & $\begin{array}{l}\text { RII(Con)= } \\
\sum \mathbf{W} /\left(\mathbf{A}^{* \mathbf{N}}\right)\end{array}$ & Rank (RI) \\
\hline 1 & Change in design by the consultant/ Errors and omissions in design & 285 & 0.559 & 2 \\
\hline 2 & Conflicts between contract documents & 292 & 0.573 & 1 \\
\hline 3 & Inadequate scope of work for contractor & 268 & 0.531 & 4 \\
\hline 4 & Lack of coordination/ communication & 268 & 0.525 & 5 \\
\hline 5 & Design complexity & 251 & 0.497 & 8 \\
\hline 6 & Inadequate working drawing details & 271 & 0.542 & 3 \\
\hline 7 & Consultant's lack of judgment and experience & 246 & 0.507 & 7 \\
\hline 8 & Non-compliant design with government regulations & 267 & 0.524 & 6 \\
\hline
\end{tabular}

From analysis of causes of variation order impacting project completion time originated from the Contractor, the major causes are found to be
"Unavailability of Skills", "Unavailability of Equipment" and "Defective workmanship". They hold rank 6,9 and 10 respectively in overall ranking.

Table 4. 10: Causes of Variation Orders from Contractor Impacting Project Completion Time

\begin{tabular}{|l|l|l|l|l|}
\hline S/N & Causes of Variation Order Impacting Project Duration & $\sum \mathbf{W}=$ & $\begin{array}{l}\mathbf{R I I}(\mathbf{C n t})= \\
\sum \mathbf{W} /\left(\mathbf{A}^{*} \mathbf{N}\right)\end{array}$ & Rank (RI) \\
\hline 1 & Unavailability of equipment & 263 & 0.516 & 2 \\
\hline 2 & Unavailability of skills & 265 & 0.525 & 1 \\
\hline 3 & Contractor's desired profitability & 255 & 0.505 & 4 \\
\hline 4 & Differing site conditions & 252 & 0.499 & 5 \\
\hline 5 & Defective workmanship & 254 & 0.508 & 3 \\
\hline 6 & Unfamiliarity with local conditions & 241 & 0.487 & 7 \\
\hline 7 & Fast track construction & 250 & 0.495 & 6 \\
\hline 8 & Poor procurement process & 236 & 0.463 & 8 \\
\hline
\end{tabular}

From analysis of causes of variation order impacting project completion time originated from the others, the major causes are found to be "Unforeseen
Problems", "Health and Safety Considerations", "Change in Economic Conditions" and "Weather Conditions". 
Aananda Raj Pokharel \& Buddhi Raj Joshi., Saudi J Eng Technol, May, 2020; 5(5): 203-230

Table 4. 11: Causes of Variation Orders Originated From Others Impacting Project Completion Time

\begin{tabular}{|l|l|l|l|l|}
\hline S/N & Causes of Variation Order Impacting Project Duration & $\sum \mathbf{W}=$ & $\begin{array}{l}\mathbf{R I I}(\mathbf{O t h}= \\
\sum \mathbf{W} /\left(\mathbf{A}^{*} \mathbf{N}\right)\end{array}$ & $\mathbf{R a n k}(\mathbf{R I})$ \\
\hline 1 & Weather conditions & 234 & 0.459 & 3 \\
\hline 2 & Health and safety considerations & 240 & 0.480 & 2 \\
\hline 3 & Change in economic conditions & 232 & 0.459 & 3 \\
\hline 4 & Unforeseen problems & 247 & 0.484 & 1 \\
\hline
\end{tabular}

Causes of Variation Order Impacting Project Cost

From the questionnaire survey carried out with the respondents, "Additional Work" has been ranked as the main cause of variation order impacting the project cost. Origin of Additional Work is Client. RII for this reason as per the respondents is 0.547 . Similarly other major causes of variation orders regarding project cost are "Lack of Cost Planning /Monitoring during Pre and Post Contract Stage" and "Poor Estimation of Original Cost".

Table 4. 12: Causes of Variation Orders Impacting Project Cost (Overall)

\begin{tabular}{|l|l|l|l|l|l|}
\hline S/N & Causes of Variation Orders Impacting Project Cost & $\begin{array}{l}\text { Origin/ } \\
\text { Source }\end{array}$ & $\begin{array}{l}\sum \mathbf{R I I}=\sum \mathbf{W} / \\
(\mathbf{A} * \mathbf{N})\end{array}$ & $\mathbf{R a n k}(\mathbf{R I})$ \\
\hline 1 & Time Overrun & All/Other & 230 & 0.451 & 16 \\
\hline 2 & Force Majeure as riots, strikes, earthquake, etc & Others & 260 & 0.510 & 7 \\
\hline 3 & Client's financial problems/ Delay in Payment of Bill & Client & 253 & 0.496 & 10 \\
\hline 4 & Change in design & Consultant & 251 & 0.492 & 11 \\
\hline 5 & Poor Project Site Management/ Poor Cost Control & Contractor & 259 & 0.513 & 6 \\
\hline 6 & Incomplete Design at the Time of Tender & Consultant & 253 & 0.501 & 9 \\
\hline 7 & Poor Estimation of Original Cost & Consultant & 272 & 0.533 & 3 \\
\hline 8 & $\begin{array}{l}\text { Lack of Cost Planning/ Monitoring during pre and post } \\
\text { contract Stage }\end{array}$ & Consultant & 276 & 0.541 & 2 \\
\hline 9 & Design Complexity & Consultant & 268 & 0.525 & 4 \\
\hline 10 & Additional Work & Client & 279 & 0.547 & 1 \\
\hline 11 & $\begin{array}{l}\text { Differing site conditions (e.g. Effect of Sub Surface } \\
\text { Conditions like Rock, Soil, Water Table, etc) }\end{array}$ & Others & 264 & 0.518 & 5 \\
\hline 12 & Defective workmanship (Rework) & Contractor & 260 & 0.510 & 7 \\
\hline 13 & $\begin{array}{l}\text { Unfamiliarity with local conditions (e.g. Public } \\
\text { Disturbances, working site not clear, etc.) }\end{array}$ & Contractor & 251 & 0.492 & 11 \\
\hline 14 & Fast track construction & Contractor & 248 & 0.486 & 14 \\
\hline 15 & Health and safety considerations & Others & 247 & 0.489 & 13 \\
\hline 16 & $\begin{array}{l}\text { Change in economic conditions (e.g. Increase in Cost of } \\
\text { Raw Materials, etc.) }\end{array}$ & Others & 243 & 0.476 & 15 \\
\hline 17 & Unforeseen problems & Others & 225 & 0.441 & 17 \\
\hline
\end{tabular}

From analysis of causes of variation order impacting project cost originated from the Client, the major cause is found to be "Additional Work" and
"Client's Financial Problems/ Delay in Payment of Bill" which holds rank1 and 10 respectively in overall ranking.

Table 4. 13: Causes of Variation Orders Originating from Client Impacting Project Cost

\begin{tabular}{|l|l|l|l|l|l|}
\hline S/N & $\begin{array}{l}\text { Causes of Variation Orders Impacting Project } \\
\text { Cost }\end{array}$ & $\begin{array}{l}\text { Origin/ } \\
\text { Source }\end{array}$ & $\sum \mathbf{W}=$ & $\mathbf{R I I}=\sum \mathbf{W} /\left(\mathbf{A}^{*} \mathbf{N}\right)$ & Rank (RI) \\
\hline 1 & $\begin{array}{l}\text { Client's financial problems/ Delay in Payment of } \\
\text { Bill }\end{array}$ & Client & 253 & 0.496 & 2 \\
\hline 2 & Additional Work & Client & 279 & 0.547 & 1 \\
\hline
\end{tabular}

Similarly, from analysis of causes of variation order impacting project cost originated from the Consultant, the major causes are found to be "Lack of Cost Planning/ Monitoring during pre and post contract stage", "Poor Estimation of Original Cost", and "Design Complexity". They hold 2, 3 and 4 ranks in overall ranking. 
Aananda Raj Pokharel \& Buddhi Raj Joshi., Saudi J Eng Technol, May, 2020; 5(5): 203-230

Table 4. 14: Causes of Variation Orders Originating from Consultant Impacting Project Cost

\begin{tabular}{|l|l|l|l|l|l|}
\hline S/N & $\begin{array}{l}\text { Causes of Variation Orders Impacting Project } \\
\text { Cost }\end{array}$ & $\begin{array}{l}\text { Origin/ } \\
\text { Source }\end{array}$ & $\sum \mathbf{W}=$ & $\mathbf{R I I}=\sum \mathbf{W} /\left(\mathbf{A}^{* \mathbf{N})}\right.$ & $\mathbf{R a n k}(\mathbf{R I})$ \\
\hline 1 & Change in design & Consultant & 251 & 0.492 & 5 \\
\hline 2 & Incomplete Design at the Time of Tender & Consultant & 253 & 0.501 & 4 \\
\hline 3 & Poor Estimation of Original Cost & Consultant & 272 & 0.533 & 2 \\
\hline 4 & $\begin{array}{l}\text { Lack of Cost Planning/ Monitoring during pre and } \\
\text { post contract Stage }\end{array}$ & Consultant & 276 & 0.541 & 1 \\
\hline 5 & Design Complexity & Consultant & 268 & 0.525 & 3 \\
\hline
\end{tabular}

Similarly, the major causes of variation order impacting project cost originated from the Contractor are found to be "Poor Project Site Management/ Poor Cost Control", "Defective Workmanship" and "Unfamiliarity with Working Conditions. They hold 6, 7 and 11 ranks in overall ranking.

Table 4. 15: Causes of Variation Orders from Contractor Impacting Project Cost

\begin{tabular}{|l|l|l|l|l|l|}
\hline S/N & Causes of Variation Orders Impacting Project Cost & $\begin{array}{l}\text { Origin/ } \\
\text { Source }\end{array}$ & $\sum \mathbf{W}=$ & $\begin{array}{l}\mathbf{R I I}= \\
\sum \mathbf{W} /\left(\mathbf{A}^{*} \mathbf{N}\right)\end{array}$ & Rank (RI) \\
\hline 1 & Poor Project Site Management/ Poor Cost Control & Contractor & 259 & 0.513 & 1 \\
\hline 2 & Defective workmanship (Rework) & Contractor & 260 & 0.510 & 2 \\
\hline 3 & $\begin{array}{l}\text { Unfamiliarity with local conditions (e.g. Public } \\
\text { Disturbances, working site not clear, etc.) }\end{array}$ & Contractor & 251 & 0.492 & 3 \\
\hline 4 & Fast track construction & Contractor & 248 & 0.486 & 4 \\
\hline
\end{tabular}

Similarly, the major causes of variation order impacting project cost originated from the Others are found to be "Differing Site Conditions", "Force
Majeure as riots, strikes, earthquakes, etc", "Health and safety considerations". They hold 5,7 and 13 ranks in overall ranking.

Table 4. 16: Causes of Variation Orders Originating from Others Impacting Project Cost

\begin{tabular}{|l|l|l|l|l|l|}
\hline S/N & Causes of Variation Orders Impacting Project Cost & $\begin{array}{l}\text { Origin/ } \\
\text { Source }\end{array}$ & $\sum \mathbf{W}=$ & $\begin{array}{l}\mathbf{R I I}= \\
\sum \mathbf{W} /\left(\mathbf{A}^{*} \mathbf{N}\right)\end{array}$ & Rank (RI) \\
\hline 1 & Force Majeure as riots, strikes, earthquake, etc & Others & 260 & 0.510 & 2 \\
\hline 2 & Health and safety considerations & Others & 247 & 0.489 & 3 \\
\hline 3 & $\begin{array}{l}\text { Change in economic conditions (e.g. Increase in Cost of } \\
\text { Raw Materials, etc.) }\end{array}$ & Others & 243 & 0.476 & 4 \\
\hline 4 & Unforeseen problems & Others & 225 & 0.441 & 6 \\
\hline 5 & Time Overrun & All/Other & 230 & 0.451 & 5 \\
\hline 6 & $\begin{array}{l}\text { Differing site conditions (e.g. Effect of Sub Surface } \\
\text { Conditions like Rock, Soil, Water Table, etc) }\end{array}$ & Others & 264 & 0.518 & 1 \\
\hline
\end{tabular}

Opinion of Key Informants on Results of Questionnaire Survey Regarding Project Completion Time

From the key informant interview, nine out of twelve respondents agreed on the results of questionnaire survey. 2 key informants from the client,
1 from the consultant, 3 from the contractor and 3 from the user's committee agreed that the causes of variation orders impacting project cost and duration compliance with the results of the questionnaire survey.

Table 4. 17: Opinion of Key Informants on Results of Questionnaire Survey Regarding Project Completion Time

\begin{tabular}{|l|l|l|l|l|l|}
\hline \multirow{2}{*}{ Responses } & \multicolumn{5}{|c|}{ Representative } \\
\cline { 2 - 6 } & Client & Consultant & Contractor & User's Committee & Total \\
\hline Agree & 2 & 1 & 3 & 3 & $\mathbf{9}$ \\
\hline Disagree & 1 & 2 & 0 & 0 & 3 \\
\hline
\end{tabular}

According to the informants the main conflict was on the standards of the pipelines where the contractor argued to have used HDPE pipes with NS standards provided by the Nepal Bureau of Standards and Metrology. This conflict stopped the works for more that 204 days. Earthquake also hampered the speed at the same time. After this conflict total works of pipeline networking system was redesigned and this also resulted in rework and further delay. Similarly change in design of road works by introducing rigid pavement works stopped the works as well. Working drawings of the redesign could not be provided to the contractor in time. So these are the major causes of project time extension. 
Aananda Raj Pokharel \& Buddhi Raj Joshi., Saudi J Eng Technol, May, 2020; 5(5): 203-230

However, three of the respondents disagreed on the results. According to them the only cause of project delay was the carelessness of the contractor.
Opinion of Key Informants on Results of Questionnaire Survey Regarding Project Cost

From the key informant interview, all the twelve respondents agreed on the results of questionnaire survey.

Table 4. 18: Opinion of Key Informants on Results of Questionnaire Survey Regarding Project Cost

\begin{tabular}{|l|l|l|l|l|l|}
\hline \multirow{2}{*}{ Responses } & \multicolumn{5}{|c|}{ Representative } \\
\cline { 2 - 6 } & Client & Consultant & Contractor & User's Committee & Total \\
\hline Agree & 3 & 3 & 3 & 3 & $\mathbf{1 2}$ \\
\hline Disagree & 0 & 0 & 0 & 0 & 0 \\
\hline
\end{tabular}

From the study of the contract documents, interim payment certificates and project related letters, various variation orders have been identified along with their severity to the project. The variation of works is listed in Table 4.1 below. According to the table, it is known that the major variations include addition of various works and also alteration of works from initial design.

Table 4. 19: List of Variation of Works in INLPP (II)

\begin{tabular}{|c|c|c|c|}
\hline $\mathbf{S} / \mathbf{N}$ & Bill Name & Variation of Works & Variation Type \\
\hline 1 & General Items & $\begin{array}{l}\text { Overlay of } 10 \mathrm{~cm} \text { thick gravel sub base thorough out the road network } \\
\text { and additional } 10 \mathrm{~cm} \text { thick gravel sub base over the pipe line } \\
\text { networking works }\end{array}$ & Addition \\
\hline 2 & \multirow[t]{6}{*}{ Road Works } & Uplift of all manhole and manhole covers & Addition \\
\hline 3 & & Addition of Rigid Pavement works as introduced by change in design & Alteration \\
\hline 4 & & Subtraction of Asphalt Concrete in Rigid Pavement Road Sections & Alteration \\
\hline 5 & & Remove all the reinforcement from Tick Drain & Omission \\
\hline 6 & & Maintenance/ Addition of Catch pit & Addition \\
\hline 7 & & Maintenance of Sever Line/ Hume pipe laying Works & Addition \\
\hline 8 & \multirow{2}{*}{$\begin{array}{l}\text { Deep Tube Well } \\
\text { Works }\end{array}$} & Depth of Well changed from $180 \mathrm{~m}$ to $174 \mathrm{~m}$ & Subtraction \\
\hline 9 & & $\begin{array}{l}\text { Down The Hole method used by Contractor but rotary method to be } \\
\text { used as per specifications, so rework was done by contractor }\end{array}$ & Alteration \\
\hline \multirow[t]{6}{*}{10} & \multirow{6}{*}{$\begin{array}{l}\text { Water Supply } \\
\text { Transmission and } \\
\text { Distribution line } \\
\text { Pipe Networking } \\
\text { works }\end{array}$} & Complete redesign of pipeline networking was done & Alteration \\
\hline & & Introduction of New pipe sizes and pressure capacity & Alteration \\
\hline & & Addition of all the fittings and accessories & Addition \\
\hline & & Connection charge inside valve chamber introduced & Addition \\
\hline & & Quantity of Earthwork increased & Addition \\
\hline & & $\begin{array}{l}\text { Introduction of DI Pipes and fittings for Inlet and Outlet of Overhead } \\
\text { Reservoir Tank }\end{array}$ & Addition \\
\hline \multirow[t]{2}{*}{11} & \multirow[t]{2}{*}{ Civil Works } & Removal of 20 cum Sump Well & Omission \\
\hline & & Increase in number of Valve chamber from 127 to 149 & Addition \\
\hline 12 & Electrical Works & Removal of all works under the bill & Omission \\
\hline
\end{tabular}
Source: Client (INLPP-II)

\section{Impact of Time Overrun in Cost Overrun}

The questionnaire survey shows that the major impact of time overrun on direct cost overrun are due to increase in material cost and labor cost. The impact on impact cost and labor cost can be measured from the price escalation.

Table 4. 20: Impacts of Time Overrun on Construction Cost

\begin{tabular}{|l|l|l|l|l|l|}
\hline S/N & $\begin{array}{l}\text { Project Cost Variation due to Completion Time } \\
\text { Variation }\end{array}$ & Impact On & $\sum \mathbf{W}=$ & $\begin{array}{l}\text { RII= } \\
/(\mathbf{A} * \mathbf{N})\end{array}$ & Rank (RI) \\
\hline A & $\begin{array}{l}\text { What are the impacts on direct cost due to change in } \\
\text { project completion time? }\end{array}$ & \multicolumn{3}{|l|}{} \\
\hline 1 & Site/ Camping Facilities & Contractor & 214 & 0.424 & 6 \\
\hline 2 & Logistics and Office Equipments & Three Parties & 259 & 0.513 & 4 \\
\hline 3 & Construction Equipments & Contractor & 249 & 0.498 & 5 \\
\hline 4 & Change in Site Conditions (e.g. Need of Rework, etc.) & Client/ Contractor & 304 & 0.602 & 3 \\
\hline 5 & Material Cost & Contractor & 334 & 0.668 & 1 \\
\hline 6 & Labor Cost & Contractor & 334 & 0.661 & 2 \\
\hline
\end{tabular}


Aananda Raj Pokharel \& Buddhi Raj Joshi., Saudi J Eng Technol, May, 2020; 5(5): 203-230

\begin{tabular}{|l|l|l|l|l|l|}
\hline \hline B & What are the impacts on indirect cost due to change in & \multicolumn{4}{|l|}{} \\
& project completion time? & Contractor & 237 & 0.469 & 3 \\
\hline 1 & Insurance & Client/ Contractor & 244 & 0.483 & 1 \\
\hline 2 & Interest during Construction & Client/ Contractor & 234 & 0.463 & 4 \\
\hline 3 & Project Supervision/ Management and Engineering & Client & 241 & 0.482 & 2 \\
\hline 4 & Increase in Cost on Successive Contract & Client/Contractor & 229 & 0.453 & 5 \\
\hline 5 & Social Contribution & All Three Parties & 224 & 0.444 & 6 \\
\hline 6 & Miscellaneous and Contingencies & &
\end{tabular}

Opinion of Informants on Impacts of Time Overrun in Cost Overrun.

Table 4. 21: Opinion of Key Informants on Results of Questionnaire Survey Regarding Impacts of Time Overrun in Cost Overrun

\begin{tabular}{|l|l|l|l|l|l|}
\hline \multirow{2}{*}{ Responses } & \multicolumn{5}{l}{ Representative } \\
\cline { 2 - 6 } & Client & Consultant & Contractor & User's Committee & Total \\
\hline Agree & 3 & 3 & 3 & 3 & $\mathbf{1 2}$ \\
\hline Disagree & 0 & 0 & 0 & 0 & $\mathbf{0}$ \\
\hline
\end{tabular}

All the informants of key informant interview agreed on the results of questionnaire survey regarding impacts of time over in cost overrun. Direct cost was increased by increase in cost of material cost and labor cost in market. As the project time increased the cost of material and labor increased due to inflation. Similarly, reworks had to be done due to change in site conditions. Gravel works which was already completed was swept away by rain and rework had to be done. Manholes and trenches excavated for water supply networking works was filled up by debris and had to be re-excavated. Many houses were constructed within the period. They dumped construction materials on roads. This created difficulty in removal of those materials and incurred cost to the contractor.
Similarly, interest during construction and cost of successive contract are main impact of time overrun on project cost according to the key informants also. Clearly, increase in cost of project incurs more money. The project has to bear the interest for the extra cost which is not calculated in direct cost. Similarly, the project had planned to continue successive contract after completion the contract under study. However, due to delay in completion of works under contract, the cost of successive contract was also hampered and incurred extra cost before its bidding process.

The project has provided price escalation to the contractor. Increase in cost of material and labor is incorporated by price escalation. The detail of price escalation approved by the Client is shown in Table 4.16 .

Table 4. 22: Details of Price Escalation of the Project Cost (NPR)

\begin{tabular}{|l|l|l|}
\hline S/N & Interim Payment certificate & Escalation Amount (In Rupees) \\
\hline 1 & IPC 1 & $1,66,958.1$ \\
\hline 2 & IPC 2 & $12,75,601.02$ \\
\hline 3 & IPC 3 & $16,92,829.79$ \\
\hline 4 & IPC 4 & $18,73,313.2$ \\
\hline 5 & IPC 5 & $31,04,498.6$ \\
\hline 6 & IPC 6 & $20,89,080.71$ \\
\hline 7 & IPC 7 & $18,, 15,881.18$ \\
\hline 8 & IPC 8 & 0 \\
\hline 9 & IPC 9 & $33,02,197.15$ \\
\hline 10 & IPC 10 & 0 \\
\hline 11 & IPC 11 & 0 \\
\hline 12 & IPC 12 & $36,04,028.61$ \\
\hline 13 & IPC 13 & $24,55,741.34$ \\
\hline & Total of Escalation & $\mathbf{2 , 1 3 , 8 0 , 1 2 9 . 7}$ \\
\hline
\end{tabular}


Aananda Raj Pokharel \& Buddhi Raj Joshi., Saudi J Eng Technol, May, 2020; 5(5): 203-230

Table 4. 23: Preventing Measures for Variation Orders from Client Impacting Project Completion Time

\begin{tabular}{|c|c|c|c|}
\hline S/ & Causes of Variation Order & $\mathrm{RII}(\mathrm{Cl})=$ & Preventing Measures \\
\hline $\mathrm{N}$ & Impacting Project Duration & $\sum \mathrm{W} /(\mathrm{A} * \mathrm{~N})$ & \\
\hline 1 & Change of schedule & 0.533 & $\begin{array}{l}\text { The client should set targets for milestones of projects and } \\
\text { prepares and remain stuck to the schedule. }\end{array}$ \\
\hline 2 & $\begin{array}{l}\text { Client's financial problems/ } \\
\text { Delay in Payment of Bill }\end{array}$ & 0.502 & $\begin{array}{l}\text { The client should prepare a good plan of maintaining and } \\
\text { allocating budget in time. }\end{array}$ \\
\hline 3 & $\begin{array}{l}\text { Impediment in prompt } \\
\text { decision making process }\end{array}$ & 0.492 & $\begin{array}{l}\text { The client should maintain communication with related } \\
\text { stakeholders and should not delay in decision making proc }\end{array}$ \\
\hline
\end{tabular}

Table 4. 24: Preventing Measures for Variation Orders from Client Impacting Project Cost

\begin{tabular}{|l|l|l|l|}
\hline S/ & Causes of Variation Orders Impacting & $\mathrm{RII}=\sum \mathrm{W} /\left(\mathrm{A}^{*} \mathrm{~N}\right)$ & Preventing Measures \\
$\mathrm{N}$ & Project Cost & 0.547 & $\begin{array}{l}\text { The client should prepare a clear vision about the } \\
\text { extent of the project and scope of the works within } \\
\text { the extent of the project. }\end{array}$ \\
\hline 1 & Additional Work & & $\begin{array}{l}\text { The client should prepare a good plan of } \\
\text { maintaining and allocating budget in time. }\end{array}$ \\
\hline 2 & $\begin{array}{l}\text { Client's financial problems/ Delay in } \\
\text { Payment of Bill }\end{array}$ & 0.496 & \\
\hline
\end{tabular}

\section{Consultant Related Preventing Measures}

Consultants, if provide proper attention, can, in most cases, prevent variation orders. Preventing measures to be taken by consultants in land pooling projects developed from the study of causes of variation orders in INLPP (II) are as follows:

Table 4. 25: Preventing Measures for Variation Orders Originating from Consultant Impacting Project Cost

\begin{tabular}{|l|l|l|l|}
\hline S/N & $\begin{array}{l}\text { Causes of Variation Orders Impacting } \\
\text { Project Cost }\end{array}$ & $\begin{array}{l}\mathrm{RII}= \\
\sum \mathrm{W} /\left(\mathrm{A}^{*} \mathrm{~N}\right)\end{array}$ & Preventing Measures \\
\hline 1 & $\begin{array}{l}\text { Lack of Cost Planning/ Monitoring } \\
\text { during pre and post contract Stage }\end{array}$ & 0.541 & $\begin{array}{l}\text { The Consultant should provide proper attention in } \\
\text { availability, allocation and utilization of budget. }\end{array}$ \\
\hline 2 & Poor Estimation of Original Cost & 0.533 & $\begin{array}{l}\text { Detailed estimate of cost should be done at the time } \\
\text { of preparation of bidding documents. }\end{array}$ \\
\hline 3 & Design Complexity & 0.525 & $\begin{array}{l}\text { As much as possible avoid complex design, consider } \\
\text { seriously the build ability in the design. Build in } \\
\text { adequate flexibility in design to respond more } \\
\text { proactively to imminent change as per site } \\
\text { requirements. }\end{array}$ \\
\hline 4 & $\begin{array}{l}\text { Incomplete Design at the Time of } \\
\text { Tender }\end{array}$ & 0.501 & $\begin{array}{l}\text { Detailed and comprehensive site investigation should } \\
\text { be done at the design phase and complete working } \\
\text { drawings should be prepared before tendering to } \\
\text { avoid delays and variations due to change in design } \\
\text { during project implementation phase. }\end{array}$ \\
\hline 5 & $\begin{array}{l}\text { Change in design } \\
\text { nang }\end{array}$ \\
\hline
\end{tabular}

Table 4. 26: Preventing Measures for Variation Orders From Consultant Impacting Project Completion Time

\begin{tabular}{|c|c|c|c|}
\hline \multirow{2}{*}{$\begin{array}{l}\mathrm{S} \\
/ \\
\mathrm{N}\end{array}$} & \multirow{2}{*}{$\begin{array}{l}\text { Causes of Variation Order Impacting } \\
\text { Project Duration }\end{array}$} & $\mathrm{RII}(\mathrm{Con})=$ & \multirow[t]{2}{*}{ Preventing Measures } \\
\hline & & $\sum \mathrm{W} /(\mathrm{A} * \mathrm{~N})$ & \\
\hline 1 & Conflicts between contract documents & 0.573 & \multirow[b]{2}{*}{$\begin{array}{l}\text { Continuous coordination and direct communication } \\
\text { with Client and end users is recommended which will } \\
\text { eliminate conflict between the contract documents, } \\
\text { design discrepancies and errors as well as omissions in } \\
\text { design and also provide opportunity for professionals to } \\
\text { review the contract documents thoroughly. }\end{array}$} \\
\hline 2 & $\begin{array}{l}\text { Change in design by the consultant/ } \\
\text { Errors and omissions in design }\end{array}$ & 0.559 & \\
\hline 3 & Inadequate working drawing details & 0.542 & $\begin{array}{l}\text { Provide comprehensive information required for easier } \\
\text { interpretation of the drawings and setting out of the } \\
\text { works. Specifications should also be standardized as } \\
\text { much as possible for ease understanding by the project } \\
\text { participants. }\end{array}$ \\
\hline 4 & $\begin{array}{l}\text { Inadequate scope of work for } \\
\text { contractor }\end{array}$ & 0.531 & $\begin{array}{l}\text { The consultant should pay proper attention on scope of } \\
\text { works defined by Client and incorporate all the extent } \\
\text { and scope of works in contracting process. }\end{array}$ \\
\hline
\end{tabular}


Aananda Raj Pokharel \& Buddhi Raj Joshi., Saudi J Eng Technol, May, 2020; 5(5): 203-230

\begin{tabular}{|l|l|l|l|}
\hline \hline 5 & Lack of coordination/ communication & 0.525 & $\begin{array}{l}\text { Continuous coordination and direct communication } \\
\text { with Client and end users is recommended which will } \\
\text { eliminate conflict between the contract documents, } \\
\text { design discrepancies and errors as well as omissions in } \\
\text { design and also provide opportunity for professionals to } \\
\text { review the contract documents thoroughly. }\end{array}$ \\
\hline 6 & $\begin{array}{l}\text { Non-compliant design with } \\
\text { government regulations }\end{array}$ & 0.524 & $\begin{array}{l}\text { Provide adequate attention in government rules and by } \\
\text { laws to ensure that the design remains within the rules } \\
\text { and by laws. }\end{array}$ \\
\hline 7 & $\begin{array}{l}\text { Consultant's lack of judgment and } \\
\text { experience }\end{array}$ & 0.507 & $\begin{array}{l}\text { Consultant should hire experienced experts of related } \\
\text { field in design and implementation phase both. }\end{array}$ \\
\hline 8 Design complexity & 0.497 & $\begin{array}{l}\text { As much as possible avoid complex design, consider } \\
\text { seriously the build ability in the design. Build in } \\
\text { adequate flexibility in design to respond more } \\
\text { proactively to imminent change as per site } \\
\text { requirements. }\end{array}$ \\
\hline
\end{tabular}

\section{Contractor Related Preventing Measures}

Contractor is the major stakeholder who actually materializes the project in real field. Preventing measures taken by contractor in correct time to avoid or reduce variation orders can significantly affect the project positively in its successful completion. The following preventing measures have been developed from the study of causes of variation orders in INLPP (II):

Table 4. 27: Preventing Measures for Variation Orders From Contractor Impacting Project Completion Time

\begin{tabular}{|c|c|c|c|}
\hline $\mathbf{S} / \mathbf{N}$ & $\begin{array}{l}\text { Causes of Variation Order } \\
\text { Impacting Project } \\
\text { Duration }\end{array}$ & $\begin{array}{l}\text { RII }(\mathbf{C n t})= \\
\sum \mathbf{W} /(\mathbf{A} * \mathbf{N})\end{array}$ & Preventing Measures \\
\hline 1 & Unavailability of skills & 0.525 & \multirow{2}{*}{$\begin{array}{l}\text { Ensure the use of skillful manpower in respective jobs and also } \\
\text { the use of proper equipment and technology as defined in } \\
\text { specifications. }\end{array}$} \\
\hline 2 & Unavailability of equipment & 0.516 & \\
\hline 3 & Defective workmanship & 0.508 & \multirow{2}{*}{$\begin{array}{l}\text { Never prioritize profitability and fast track construction over } \\
\text { quality of works to avoid rework. }\end{array}$} \\
\hline 4 & $\begin{array}{l}\text { Contractor's desired } \\
\text { Profitability }\end{array}$ & 0.505 & \\
\hline 5 & Differing site conditions & 0.499 & $\begin{array}{l}\text { Carry out extensive site investigation prior to mobilization for } \\
\text { work to eliminate or minimize differing site conditions and } \\
\text { unfamiliarity with local conditions. }\end{array}$ \\
\hline 6 & Fast track construction & 0.495 & $\begin{array}{l}\text { Never prioritize profitability and fast track construction over } \\
\text { quality of works to avoid rework. }\end{array}$ \\
\hline 7 & $\begin{array}{l}\text { Unfamiliarity with local } \\
\text { conditions }\end{array}$ & 0.487 & $\begin{array}{l}\text { Carry out extensive site investigation prior to mobilization for } \\
\text { work to eliminate or minimize differing site conditions and } \\
\text { unfamiliarity with local conditions. }\end{array}$ \\
\hline 8 & $\begin{array}{l}\text { Poor procurement process } \\
\text { (sub contracting) }\end{array}$ & 0.463 & $\begin{array}{l}\text { Start procurement of materials, equipments and manpower in } \\
\text { proper time and avoid rush hour procurement. }\end{array}$ \\
\hline
\end{tabular}

Table 4. 28: Preventing Measures for Causes of Variation Orders from Contractor Impacting Project Cost

\begin{tabular}{|l|l|l|l|}
\hline S/N & $\begin{array}{l}\text { Causes of Variation Orders } \\
\text { Impacting Project Cost }\end{array}$ & $\begin{array}{l}\mathbf{R I I}= \\
\sum \mathbf{W} /\left(\mathbf{A}^{*} \mathbf{N}\right)\end{array}$ & Preventing Measures \\
\hline 1 & $\begin{array}{l}\text { Poor Project Site Management/ Poor } \\
\text { Cost Control }\end{array}$ & 0.513 & $\begin{array}{l}\text { Deploy sufficient and experienced supervision, } \\
\text { monitoring and control team to control defective } \\
\text { workmanship. }\end{array}$ \\
\hline 2 & Defective workmanship (Rework) & 0.51 & $\begin{array}{l}\text { Never prioritize profitability and fast track } \\
\text { construction over quality of works to avoid rework. }\end{array}$ \\
\hline 3 & $\begin{array}{l}\text { Unfamiliarity with local conditions } \\
\text { (e.g. Public Disturbances, working } \\
\text { site not clear, etc.) }\end{array}$ & 0.492 & $\begin{array}{l}\text { Carry out extensive site investigation prior to } \\
\text { mobilization for work to eliminate or minimize } \\
\text { differing site conditions and unfamiliarity with } \\
\text { local conditions. }\end{array}$ \\
\hline 4 & Fast track construction & 0.486 & $\begin{array}{l}\text { Never prioritize profitability and fast track } \\
\text { construction over quality of works to avoid rework. }\end{array}$ \\
\hline
\end{tabular}




\section{CONCLUSION}

Government of Nepal has been planning to develop modern cities through land pooling programs as per the Town Development Act 2045. As it involves wide extent and varieties of construction works in a large volume, variation of works is common in such projects. The main objective of this study is to identify the origin and causes of variation orders and their impacts in project cost and completion time. The study is conducted in Ichangu Narayan (Raniban) Land Pooling Project (Phase II) (INLPP (II)) and the status of variation orders, their origin, causes and impacts in project cost and completion time is analyzed to develop preventing measures which can be beneficial in upcoming similar projects.

Primary data were collected from the questionnaire survey, key informant interview and field study. Contract documents, interim payment certificates and project related letters and documents for the study were obtained from the client, the design consultant and the contractor. The secondary data were collected by means of desk study, relevant literature and text books review, maps and drawings and internet sources.

Likert scales have been used for ranking the perception based relative importance index (RII) of respondents about causes of variation orders and key informants are interviewed to verify the results of RII. Similarly, amount and percentage of cost of works carried out up to finalization of contract are compared to the initial bill of quantities to develop the impacts of variation orders. Contracted duration is compared to completion duration to develop the impact of variation orders in project completion time.

Existence of variation orders in INLPP (II) has been noted from the study. From the study, main cause of variation orders impacting project completion time is known to be conflict between the contract documents and is originated from Consultant. Similarly, main cause of variation orders impacting project cost is additional work.

$26.50 \%$ (NPR 45,700,255.02) cost above the contract cost has been incurred directly at the completion of the project. $12.40 \%$ (NPR 21,380,129.70) of contract cost has been paid for price escalation only. Similarly, $16.96 \%$ cost for the successive contract of the project has been increased by the extension of the contract duration.

The client is recommended to prepare a clear vision about the extent of the project and be careful in selection of consultant. The consultant is recommended to maintain continuous coordination with all related parties, carry out comprehensive site investigation before design and avoid complex design. The contractor is recommended to deploy sufficient, relevant and required equipments and manpower, avoid fast track construction and carry out extensive site investigation prior to mobilization. Findings of this study will be beneficial for planners, developers, designers and contractors in future land pooling projects to develop preventing measures to eliminate or reduce variation orders.

\section{REFERENCE}

1. Charoenngam, C., Coquinco, S. T., \& Hadikusumo, B. H. W. (2003). Web-Based Application for Managing Change Orders in Construction Projects. Construction Innovation, 3:197-215.

2. Koushki, P. A., Al- Rashid, K., \& Kartam, N. (2005). Delays and cost increases in the construction of private residential projects in Kuwait. Construction Management and Economics, 23(3), 285-294.

3. Ruben, N. (2008). An analysis of the impact of variation orders on project performance. M.T.C.M. Cape Peninsula University of Technology.

4. Koskela, H. (2000). 'The gaze without eyes': video-surveillance and the changing nature of urban space. Progress in Human Geography, 24(2), 243-265.

5. Arain, F. M., \& Pheng, L. S. (2005). How Design Consultants Perceive Causes of Variation Orders for Institutional Buildings in Singapore. Architectural Engineering and Design Management, 1(3):181-196.

6. Wainwright, W. H., \& Wood, A. A. B. (1983). Variation and Final Account Procedure. $4^{\text {th }}$ ed. London: Hutchinson.

7. Finsen, E., 2005. The Building Contract - A Commentary on the JBCC Agreements. $2^{\text {nd }}$ ed. Kenwyn: Juta \& Co. Ltd.

8. Mohamed, A. A. (2001). Analysis and Management of Change Orders for combined Sewer over flow construction projects. M.E. Wayne State University.

9. Zimmerman, W. L., \& Hart, D. G. (1982). Value Engineering - A practical approach for Owners, Designers and Contractors. New York: Van Nostrand Reinhold Company.

10. PPA. (2007). Public Procurement Act- 2007. Kathmandu, Nepal: Nepal Law Commission.

11. Acharya, N. K., Lee, Y. D., \& Im, H. M. (2006). Design Errors: Tragic for the Clients. Journal of Construction Research, 7(1/2); 177-190.

12. Uyun, N. M. Y. (2007). Variation Control Affecting Construction Works for Lembaga Kemajuan Tanah Persekutuan (Felda)", Thesis, University Technologi Malaysia.

13. Gidado, K. I. (1996). Project complexity: The focal point of construction production planning. Construction Management \& Economics, 14(3), 213-225. 
14. Baccarini, D. (1996). The Concept of Project Complexity - a Review. International Journal of Project Management, 14(4):201-204.

15. Ireland, L. (2007). Project Complexity: A Brief Exposure to Difficult Situations. Retrieved on October 17, 2018, from http://www.asapm.org/asapmag/articles/PrezSez10 -07.pdf

16. Formoso, T. C., Isatto, E. L., \& Hirota, E. H. (1999). Method for Waste Control in the Building Industry., CA, USA, 26-28 July 1999:325-334. University of California, Berkeley.

17. Al-Hakim, L. (2005). Waste Identification: A Supply Chain Strategy Perspective. International Conference on Business and Information, Hong Kong. Retrieved June 29, 20018, from http://eprints.usq.edu.au/archive/00000207/01/200 5bai180.pdf

18. Ibbs, C. W. (1997). Quantitative Impacts of Project Change: Size Issues. Journal of
Construction Engineering and Management, 123(3):308-311.

19. Ssegawa, J. K., Mfolwe, K. M., Makuke, B., \& Kutua, B. (2002, November). Construction variations: a scourge or a necessity. In Proceedings of the First International Conference of CIB W107 (pp. 11-13).

20. Bower, C., Zhou, O., Zhu, W., Werder, D. J., \& Jin, S. (2000). Nucleation and growth of carbon nanotubes by microwave plasma chemical vapor deposition. Applied Physics Letters, 77(17), 2767. 2769.

21. Chan, A. P. C., \& Yeong, C. M. (1995). A Comparison of Strategies for Reducing Variations. Construction Management and Economics. 13(6):467-473.

Central Bureau of Statistics. (2011). National Population and Housing Census 2011 (National Report), Central Bureau of Statistics, Kathmandu, Nepal. 